\title{
Reactive Oxygen Species Modulation of Na/K-ATPase Regulates Fibrosis and Renal Proximal Tubular Sodium Handling
}

\author{
Jiang Liu, ${ }^{1}$ David J. Kennedy, ${ }^{2}$ Yanling Yan, ${ }^{1,3}$ and Joseph I. Shapiro1 \\ ${ }^{1}$ Department of Medicine, College of Medicine University of Toledo, 3000 Arlington Avenue, Toledo, OH 43614, USA \\ ${ }^{2}$ Department of Cell Biology, Lerner Research Institute, Cleveland Clinic, 9500 Euclid Avenue, Cleveland, OH 44195, USA \\ ${ }^{3}$ Institute of Biomedical Engineering, Yanshan University, Qinhuangdao 066004, China
}

Correspondence should be addressed to Joseph I. Shapiro, joseph.shapiro@utoledo.edu

Received 7 October 2011; Accepted 7 November 2011

Academic Editor: Ayse Balat

Copyright (C) 2012 Jiang Liu et al. This is an open access article distributed under the Creative Commons Attribution License, which permits unrestricted use, distribution, and reproduction in any medium, provided the original work is properly cited.

\begin{abstract}
$\mathrm{The} \mathrm{Na} / \mathrm{K}$-ATPase is the primary force regulating renal sodium handling and plays a key role in both ion homeostasis and blood pressure regulation. Recently, cardiotonic steroids (CTS)-mediated Na/K-ATPase signaling has been shown to regulate fibrosis, renal proximal tubule (RPT) sodium reabsorption, and experimental Dahl salt-sensitive hypertension in response to a high-salt diet. Reactive oxygen species (ROS) are an important modulator of nephron ion transport. As there is limited knowledge regarding the role of ROS-mediated fibrosis and RPT sodium reabsorption through the Na/K-ATPase, the focus of this review is to examine the possible role of ROS in the regulation of $\mathrm{Na} / \mathrm{K}$-ATPase activity, its signaling, fibrosis, and RPT sodium reabsorption.
\end{abstract}

\section{Introduction}

According to the American Heart Association (AHA), over 70 million people in the United States aged 20 and older have high blood pressure (BP). The cause of 90-95 percent of the cases of high BP is unknown, yet in the last decade the associated morbidity and mortality from high BP has increased precipitously. In the 2008 AHA Scientific Statement [1], excessive dietary salt intake is listed as one of the major lifestyle factors which significantly contributes to the development of hypertension and tends to be more pronounced in typical salt-sensitive patients. Modest dietary salt restriction and diuretic therapy, therefore, are recommended for treatment of resistant hypertension, especially in the salt-sensitive subgroup $[1,2]$. Renal sodium handling is a key determinant of long-term BP regulation [3]. The relationship between dietary sodium, salt sensitivity, and BP has been established on an epidemiological and clinical basis. It is estimated that hypertension affects $25 \%$ to $35 \%$ of the world population aged 18 and older [4], and more hypertensive subjects $(\sim 50 \%)$ are significantly salt sensitive than normotensive subjects $(\sim 25 \%)$ [5]. In the DASHSodium clinical trial, BP reduction was correlated with sodium restriction in the salt-sensitive subjects regardless of diet [6]. Interestingly, animal renal cross-transplantation experiments [7-10] and studies of human renal transplantation [11] demonstrate that BP levels "travel with the donor's kidney," providing compelling evidence for the role of renal function in the pathogenesis of hypertension. In clinical and experimental models, renal proximal tubule (RPT) sodium handling accounts for over $60 \%$ reabsorption of filtered sodium and is an independent determinant of BP response to salt intake, playing a critical role in the pathogenesis of salt-sensitive hypertension. Recently, accumulating data indicate that cardiotonic steroids (CTS) signaling through the $\mathrm{Na} / \mathrm{K}$-ATPase contribute to RPT sodium handling and salt sensitivity [12-18].

\section{CTS and Na/K-ATPase Signaling}

CTS (also known as endogenous digitalis-like substances) include plant-derived digitalis drugs, such as digoxin and ouabain, and vertebrate-derived aglycones such as bufalin and marinobufagenin $(\mathrm{MBG})[16,18]$. Recent studies have identified both ouabain and MBG as endogenous steroids whose production, and secretion are regulated by stimuli including angiotensin II (Ang II) [18-21]. The Na/K-ATPase 
belongs to the P-type ATPases family and consists of two noncovalently linked $\alpha$ and $\beta$ subunits [22-24]. Several $\alpha$ and $\beta$ isoforms, expressed in a tissue-specific manner, have been identified and functionally characterized [22-25]. The $\alpha 1$ subunit contains multiple structural motifs that interact with soluble, membrane and structural proteins including Src, caveolin-1, phospholipase C- $\gamma$, PI3 kinase, IP3 receptor, $\mathrm{BiP}$, calnexin, cofilin, and ankyrin [26-36]. Binding to these proteins not only regulates the ion-pumping function of the enzyme, but it also conveys signal-transducing functions to the $\mathrm{Na} / \mathrm{K}$-ATPase $[18,32,37-39]$. In LLC-PK1 cells, the $\mathrm{Na} / \mathrm{K}$-ATPase $\alpha 1$ subunit and Src form a functional receptor in which the binding of CTS to the $\alpha 1$ subunit activates Src and consequent signaling cascade [39]. The signaling function of the $\mathrm{Na} / \mathrm{K}-\mathrm{ATP}$ ase regulates numerous cell functions in various types of organs and cells including cell motility, cell proliferation, cancer, endothelin release, glycogen synthesis, apoptosis, hypertension, intracellular calcium signaling, cardiac hypertrophy, cardiac remodeling, renal remodeling, epithelial cell tight junction, vascular tone homeostasis, and sodium homeostasis [26, 40-59]. The topic of CTS-Na/K-ATPase signaling and its downstream pathophysiological implications has been extensively reviewed in the last few years $[12-16,18,21,32,39,59-64]$, and we will not discuss them in detail in this review.

\section{CTS and Sodium Homeostasis}

Endogenous CTS were first proposed many years ago to function as a natriuretic hormone. Although their pathophysiological significance has been a subject of debate for many years [65], the concept of a natriuretic hormone is supported by the experimental observations in animal models of ouabain-induced natriuresis $[66,67]$. Recently, several elegant reports have confirmed this concept with different approaches. Gene replacement studies have unequivocally demonstrated an important role of endogenous CTS in regulation of renal sodium excretion and $\mathrm{BP}[68,69]$. In transgenic mice expressing ouabain-sensitive $\mathrm{Na} / \mathrm{K}$-ATPase $\boldsymbol{\alpha} 1$ subunit, a significant observation is an augmented natriuretic response to both acute salt load and ouabain infusion, indicating that the ouabain-binding site of $\mathrm{Na} / \mathrm{K}$ ATPase $\boldsymbol{\alpha} 1$ subunit participates in the natriuretic response to salt load by responding to endogenous ouabain. Moreover, the augmented natriuretic response in the ouabain-sensitive $\boldsymbol{\alpha} 1$ isoform mice can be blocked with administration of an anti-digoxin antibody fragment $[68,69]$. In normal male Wistar rats, endogenous circulatory ouabain has physiological roles controlling vasculature tone and sodium homeostasis, showing endogenous ouabain regulates renal sodium excretion in normal animals [70]. A significant inhibition of natriuresis is observed in rats that were passively immunized with anti-ouabain antibody and in rats that were actively immunized with ouabain-albumin antigen, in which endogenous ouabain levels were reduced in both cases. Like ouabain, MBG has both natriuretic and vasoconstrictor effects $[12,71,72]$. High salt intake induced an initial transient stimulation of ouabain and a subsequent progressive increase of MBG both in Dahl salt-sensitive (S) rats and in humans $[12,73]$. In Dahl S rats, the increase in natriuresis stimulated by an acute salt loading is prevented by administration of both an anti-ouabain antibody and an antiMBG antibody [72]. Furthermore, endogenous CTS have also been implied in age-related increases in salt sensitivity of BP in human normotensive subjects [73]. It is estimated that approximately $50 \%$ of humans with untreated essential hypertension have significantly elevated levels of endogenous ouabain [74] which is involved in the regulation of vascular tone homeostasis through stimulation of interaction between the $\mathrm{Na} / \mathrm{K}$-ATPase and sodium/calcium exchanger [59]. In normotensive human males, both a high salt diet and systematic sodium depletion (by hydrochlorothiazide) significantly increase plasma ouabain concentration [75].

Release of endogenous ouabain from the brain hypothalamus stimulated by a high salt diet leads to inhibition of the $\mathrm{Na} / \mathrm{K}$-ATPase activity and central sympathetic activation (reviewed in $[76,77]$ ), which plays a crucial role in the pressor effects of high salt intake in spontaneously hypertensive rats (SHR) and Dahl S rats. In Dahl S rats, elevation in brain ouabain increased MBG secretion from the adrenal cortex, and this effect was blocked by the AT1 receptor antagonist losartan $[78,79]$. The data suggest that the observed CTSinduced natriuretic effect might be a result of the combined effects of ouabain and MBG [60]. Furthermore, CTS not only induced hypertension in rats but also caused significant cardiovascular remodeling and natriuresis independent of their effect on BP $[49,51,70,80,81]$.

\section{CTS and Oxidative Stress in Cardiac and Renal Fibrosis}

CTS binding to the Na/K-ATPase induces cellular reactive oxygen species (ROS) production and its downstream effects, such as cardiac and renal fibrosis, and these effects can be prevented by ROS scavenging [80, 82-84]. In kidney and heart, the central role of CTS in the development of fibrosis has been demonstrated both in vivo, in the partial (5/6th) nephrectomy model, and in vitro cell culture, including cardiac and renal fibroblasts. 5/6th nephrectomy increases circulating levels of MBG and stimulates cardiac fibrosis in both rat and mouse $[80,84,85]$. Rats subjected to $5 / 6$ th nephrectomy develop systemic oxidant stress that is similar to that seen in rats subjected to MBG infusion as evidenced by significant elevation of plasma carbonylated protein. Active immunization against MBG and reduction of circulating levels of MBG by adrenalectomy substantially attenuate 5/6th nephrectomy and MBG infusionmediated cardiac fibrosis and oxidant stress, an effect that is independent of $\mathrm{BP}[80,84]$. In primary culture of rat cardiac and human dermal fibroblasts as well as a cell line derived from rat renal fibroblasts, MBG and ouabain stimulate $\left[{ }^{3} \mathrm{H}\right]$ proline incorporation as well as gene and protein expression of collagen [86]. MBG induced a PLCdependant translocation of PKC- $\delta$ to the nucleus, resulting in the phosphorylation and degradation of transcription factor Friend leukemia integration-1 (Fli-1), a negative 


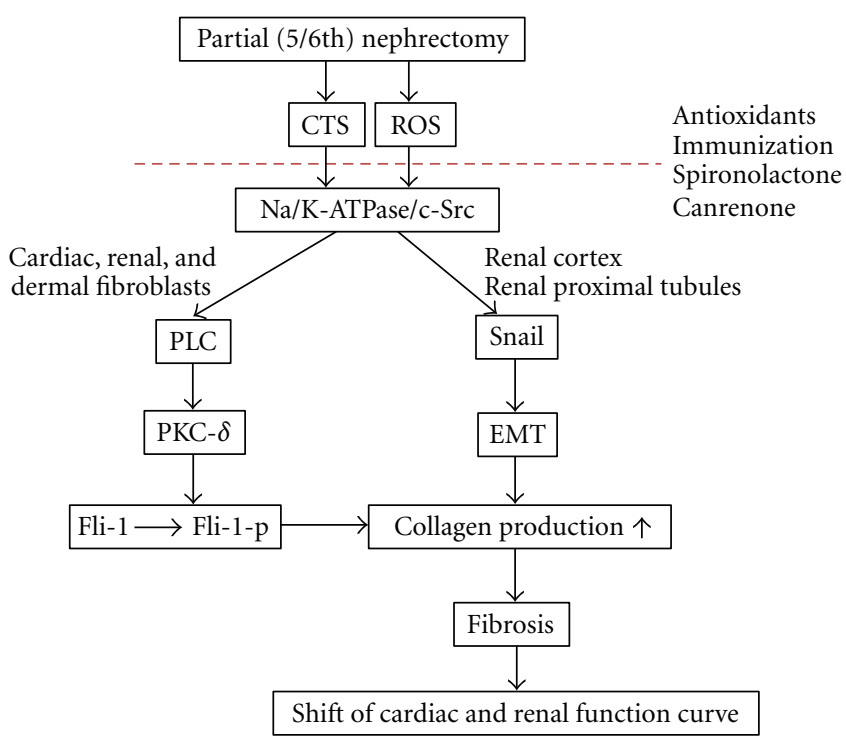

FIGURE 1: Schematic illustration of the effect of CTS on fibrosis.

regulator of collagen synthesis [86]. Both CTS-induced $\mathrm{Na} / \mathrm{K}$-ATPase signaling and oxidative stress are necessary in the pathogenesis of cardiac and renal fibrosis as evidenced by CTS-stimulated phosphorylation of both Src and MAPK which is effectively blocked not only by ROS scavenging and Src inhibition but also through possible competitive inhibition of CTS binding to $\mathrm{Na} / \mathrm{K}$-ATPase by spironolactone and canrenone $[80,84,87,88]$. MBG infusion causes renal fibrosis mainly in the cortex of the kidney by stimulation of the transcription factor Snail expression and its nuclear localization in the tubular epithelia, which is associated with epithelial-to-mesenchymal transition (EMT) during renal fibrosis [89]. This EMT phenomenon is also demonstrated in LLC-PK1 cells, indicating that MBG may cause damage of renal proximal tubules. CTS-induced fibrosis in heart and kidney might shift the cardiac and renal function curve to favor a higher set point of pressure natriuresis (Figure 1).

\section{Na/K-ATPase Signaling and RPT Sodium Handling}

It has been postulated for decades that endogenous CTS stimulated by increased sodium intake increases natriuresis and diuresis by directly inhibiting renal tubular $\mathrm{Na} / \mathrm{K}$ ATPase to prevent renal reabsorption of filtered sodium [9092]. There is accumulating evidence supporting this idea under conditions such as high salt intake, chronic renal sodium retention, renal ischemia, uremic cardiomyopathy, and volume expansion in various animal models and human beings $[12,13,15,60,62,75,93-107]$. Although the direct inhibition of the $\mathrm{Na} / \mathrm{K}$-ATPase enzymatic activity and sodium reabsorption in RPTs by CTS has not been validated, recent observations indicate that ligand-mediated RPT sodium reabsorption via Na/K-ATPase/c-Src signaling counterbalances the sodium retention-mediated increases in BP, such as that seen in salt-sensitive hypertension
[108-114]. Ouabain, a ligand of the Na/K-ATPase, activates the $\mathrm{Na} / \mathrm{K}$-ATPase/c-Src signaling pathway and subsequently redistributes basolateral $\mathrm{Na} / \mathrm{K}$-ATPase and apical sodium/hydrogen exchanger isoform 3 (NHE3) in RPTs, leading to reduced RPT sodium reabsorption and increased urinary sodium excretion.

In LLC-PK1 cells, ouabain activates $\mathrm{Na} / \mathrm{K}$-ATPase/c-Src signaling pathways and reduces cell surface $\mathrm{Na} / \mathrm{K}$-ATPase and NHE3, leading to a significant inhibition of active transcellular ${ }^{22} \mathrm{Na}^{+}$flux from the apical to basolateral compartment [108-112]. MBG, an important CTS species, and deproteinated extract of serum (derived from patients with chronic renal failure) also induce $\mathrm{Na} / \mathrm{K}$-ATPase endocytosis and inhibition of active transepithelial ${ }^{22} \mathrm{Na}^{+}$flux. However, it is still not clear how ouabain-activated $\mathrm{Na} / \mathrm{K}$-ATPase signaling regulates NHE3, since, at concentrations of ouabain used, no significant change in intracellular $\mathrm{Na}^{+}$concentration was observed [108]. Interestingly, this phenomenon is either not observed or is much less significant in MDCK cells (a canine renal distal tubule cell line). These in vitro data suggest that CTS-Na/K-ATPase signaling has a profound effect on RPT sodium handling, but not in distal tubules.

Different species of endogenous CTS show differences in the kinetics and tissue actions in response to salt loading in both animal models and in human salt-sensitive hypertensive patients $[16,18,60,75,79,105]$. The Dahl salt-resistant (R) and salt-sensitive (S) strains were developed by selective breeding of the outbred Sprague-Dawley rat strain for resistance or susceptibility to the hypertensive effects of high dietary sodium [115]. RPT sodium handling is a critical determinant of the different $\mathrm{BP}$ responses in these strains $[7,116-118]$, and there is no Na/K-ATPase $\alpha 1$ gene (Atp1a1) difference between $\mathrm{R}$ and $\mathrm{S}$ rats [119]. In comparison to Dahl S rats that eliminate excessive sodium mainly through pressure natriuresis at the expense of an elevated systolic $\mathrm{BP}$, a major response to salt loading in the Dahl $\mathrm{R}$ rats is a greater reduction in renal sodium reabsorption to eliminate excessive sodium without raising BP. Our recent in vivo observation [114] is in agreement with this hypothesis and our in vitro observations in LLC-PK1 cells. Specifically in isolated RPTs, both a high salt diet and ouabain are able to activate $\mathrm{Na} / \mathrm{K}$-ATPase/c-Src signaling pathways, leading to the redistribution of $\mathrm{Na} / \mathrm{K}-\mathrm{ATP}$ ase and NHE3 in the Dahl R but not in the $\mathrm{S}$ rats. The $\mathrm{R}$ rats show significant increases in total urinary sodium excretion and RPT-mediated fractional sodium excretion, without BP elevation [114]. While the $\mathrm{BP}$ response to salt loading in $\mathrm{R}$ and $\mathrm{S}$ rats involves many regulatory factors [117], our data indicate that impairment of the RPT Na/K-ATPase/c-Src signaling contributes to salt sensitivity. Since it failed to confirm the possible difference of $\mathrm{Na} / \mathrm{K}$-ATPase $\alpha 1$ gene (Atp1al) between $\mathrm{R}$ and $\mathrm{S}$ rats [119], other factor(s) must be present to prevent activation of $\mathrm{Na} / \mathrm{K}$-ATPase/c-Src signaling in the $\mathrm{S}$ rats. The possible effect of CTS on RPT Na/K-ATPase signaling and sodium reabsorption is summarized in Figure 2.

The SHR rat is an established model of human essential hypertension with the characteristic of vascular resistance. SHR rat develops hypertension spontaneously at the age of 7-15 weeks, regardless of salt loading, mainly through 


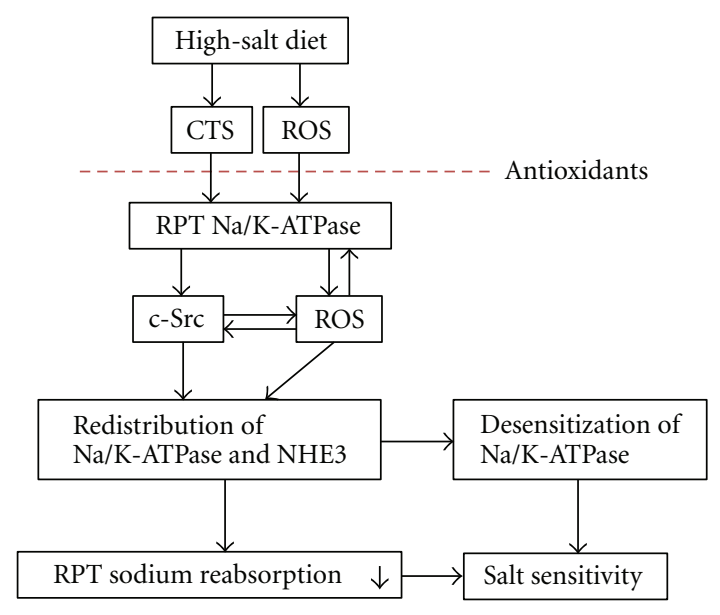

FIGURE 2: Schematic illustration of the effects of ROS and Na/KATPase signaling on RPT sodium reabsorption. CTS: cardiotonic steroids; RPT: renal proximal tubules.

increase in peripheral vascular resistance [120] including renal vascular resistance. Interestingly, either reduction of dietary vitamin $\mathrm{E}$ or caloric restriction without sodium restriction prevents the development of hypertension [121, 122]. Like Dahl S rats, SHR rats eliminate excessive sodium via a pressure-natriuresis mechanism but have significant lower BP response to a high salt diet and higher systolic BP to eliminate the same amount of sodium when compared to Dahl S rats [123-126]. Most interestingly, comparing to control Wistar-Kyoto (WKY) rats, regulation of the $\mathrm{Na} / \mathrm{K}$-ATPase and NHE3 with both aging and oxidative stress have been shown contributed to the development and maintenance of hypertension in the SHR [127-135]. In renal cortical (proximal) tubules, activity and protein levels of NHE-3 are significantly higher in SHR than agematched WKY rats at all stages during the development and maintenance of hypertension. When NHE3 function is determined by the rate of bicarbonate reabsorption by in vivo stationary microperfusion in RPT, young SHR rats show higher NHE3 activity than adult SHR and WKY rats, and this is accompanied by changes in NHE3 phosphorylation and distribution. In young SHR rats, the RPT Na/K-ATPase activity is significantly higher than in age-matched WKY, which can be prevented by treatment of the diuretic drug hydrochlorothiazide. However, the Na-K-ATPase activity in medullary thick ascending limb, cortical thick ascending limb, and distal tubule is significantly lower in young SHR rats than in age-matched WKY rats. There were no significant differences in $\mathrm{Na} / \mathrm{K}$-ATPase activity in these nephron segments in adult SHR and WKY rats, nor in collecting duct segments of young and adult SHR and age-matched WKY rats. Interestingly, however, the $\mathrm{Na} / \mathrm{K}$-ATPase $\boldsymbol{\alpha} 1$ subunit gene expression is lower in both young and adult SHR rats than age-matched WKY rats, indicating a posttranscriptional regulation.

Recent study indicates that SHR rats have enhanced renal superoxide generation and NADPH oxidase (NOX) expression in both vascular and renal tissue before and after development of hypertension [136]. Elevated basal level of superoxide inhibits proximal tubule NHE3 activity and fluid reabsorption in SHR rats in comparison to WKY rats. This effect is prevented by the NOX inhibitor apocynin or knockdown of the critical NOX subunit $\mathrm{p} 22^{\text {phox }}$ with small interfering RNA, indicating that increased basal level of superoxide impairs RPT function [137]. Furthermore, in Sprague-Dawley rats, oxidative stress impairs Ang IImediated regulation of NHE3 [138].

\section{Oxidative Stress and Regulation of $\mathrm{Na} / \mathrm{K}$-ATPase}

Many stimuli including hypoxia and dopamine induce a cell- and tissue-specific endocytosis and exocytosis of $\mathrm{Na} / \mathrm{K}$ ATPase and a change in Na/K-ATPase activity [33, 61, 139]. Ouabain-stimulated ROS generation functions as a second messenger in ouabain-activated $\mathrm{Na} / \mathrm{K}$-ATPase signaling in isolated rat cardiac myocytes [82, 140-142]. Binding of ouabain to the $\mathrm{Na}$ /K-ATPase activates Src kinase, which in turn transactivates EGFR, leading to activation of the RasRaf-MEK-ERK pathway [32, 39, 63]. Ras activation leads to the activation of MAPK and increase in $\left[\mathrm{Ca}^{2+}\right]_{i}$ which result in opening of mitochondrial ATP-sensitive $\mathrm{K}^{+}$channels [142] and generation of mitochondrial ROS [82, 141]. ROS subsequently activate NF- $\kappa \mathrm{B}[141,143]$ and slow $\left[\mathrm{Ca}^{2+}\right]_{\mathrm{i}}$ oscillations at nanomolar ouabain concentrations [40]. Additionally, ouabain-induced generation of ROS in neonatal myocytes is antagonized by overexpression of a dominant negative Ras as well as myxothiazol/diphenyleneiodonium, indicating a mitochondrial origin of the Ras-dependent ROS generation [82]. Ouabain also stimulates ROS generation in other cell types [144-146]. Conversely, oxidative stress can activate the $\mathrm{Na} / \mathrm{K}$-ATPase signaling. Both a bolus of $\mathrm{H}_{2} \mathrm{O}_{2}$ and exogenously added glucose oxidase (which generates a sustained low level of $\mathrm{H}_{2} \mathrm{O}_{2}$ by consuming glucose) activates $\mathrm{Na} / \mathrm{K}$-ATPase signaling in cardiac myocytes [140]. Pretreatment with the antioxidant $\mathrm{N}$-acetyl cysteine (NAC) prevents ouabain-Na/K-ATPase signaling and its downstream effects. Moreover, infusion of CTS causes ROS generation and protein oxidation in experimental animals $[80,147]$.

The redox sensitivity of the Na/K-ATPase was first demonstrated in electric eels with treatment of $\mathrm{H}_{2} \mathrm{O}_{2}$ [148]. This phenomenon was further observed in a wide range of animal species, tissues, and other species of ROS such as hypochlorous anion, hydroxyl radicals, superoxide, hyperchlorite anions, and singlet oxygen. It has been shown that the $\mathrm{Na} / \mathrm{K}$ ATPase in skeletal muscle is redox-sensitive and infusion of NAC attenuated ROS-mediated inhibition of maximal pump activity [149]. In dog kidney, oxidative modification of kidney $\mathrm{Na} / \mathrm{K}$-ATPase by $\mathrm{H}_{2} \mathrm{O}_{2}$ was accompanied by a decrease in the amount of sulfhydryl (SH) groups [150] and, importantly, oxidative modification can result in formation of $\mathrm{Na} / \mathrm{K}$-ATPase oligomeric structure [151]. The differences in the number, location, and accessibility of SH groups in $\mathrm{Na} / \mathrm{K}$-ATPase isozymes might predict their oxidative stability [152]. Different antioxidant enzymes, natural or synthetic antioxidants, and some inhibitors of oxidase activity can 
attenuate ROS mediated inhibition of $\mathrm{Na} / \mathrm{K}$-ATPase activity. ROS are known to inhibit $\mathrm{Na} / \mathrm{K}$-ATPase activity in different types of cells as well. Interestingly, the $\mathrm{Na} / \mathrm{K}$-ATPase in rat cerebellar granule cells are redox-sensitive with an "optimal redox potential range," where ROS levels out of this "optimal range" are capable of inhibiting $\mathrm{Na} / \mathrm{K}$-ATPase activity [153]. While the Na/K-ATPase does not contain heme groups, it does contain cysteine residues located in $\alpha$ subunit cytosolic loops which may determine the redox sensitivity of the $\alpha$ subunit. The sensitivity of the $\mathrm{Na} / \mathrm{K}$-ATPase to redox and oxygen status, the regulatory factors which govern these interactions, and the implied molecular mechanism were recently reviewed [154].

Increases in ROS can oxidize the $\mathrm{Na} / \mathrm{K}$-ATPase $\alpha / \beta$ subunits and its independent regulator FXYD proteins. This oxidation inhibits its activity and promotes its susceptibility to degradation by proteasomal and endosomal/lysosomal proteolytic pathways in different cell types including cardiac myocytes, vascular smooth muscle cells, and RPTs [155166]. It appears that the oxidized modification of the $\mathrm{Na} / \mathrm{K}-$ ATPase is a reversible, redox-sensitive modification. However, purified enzyme has also been shown to be irreversibly inhibited upon exposure to hydrogen peroxide, the superoxide anion, and the hydroxyl radical [158]. The regulation of renal $\mathrm{Na} / \mathrm{K}$-ATPase $\boldsymbol{\alpha} 1$ by oxidants is not dependent on the ouabain sensitivity of the $\alpha 1$ subunit per se. It appears that the $\boldsymbol{\alpha} 2$ and $\boldsymbol{\alpha} 3$ subunits are more sensitive to oxidants than the $\alpha 1$ subunit, and ouabain-sensitive $\alpha 1$ (canine) and insensitive- $\boldsymbol{\alpha} 1$ (rat) have similar sensitivity to oxidants, suggesting the regulation of $\boldsymbol{\alpha} 1$ by ROS is not species specific. Furthermore, ROS accelerates degradation of the oxidatively damaged $\mathrm{Na} / \mathrm{K}$-ATPase and the $\boldsymbol{\alpha} 2$ and $\boldsymbol{\alpha} 3$ subunits, which also appear to be more susceptible to degradation than the $\boldsymbol{\alpha} 1$ subunit [159]. These studies indicate that differential oxidant sensitivities of the $\mathrm{Na} / \mathrm{K}$-ATPase subunits are dictated by the primary sequences of different subunits and different subunit compositions of the various tissues may contribute to their relative susceptibilities to oxidant stress. In the RPT cell line originated from WKY rats, cadmium, a ROS generator, stimulates ROS production and causes a toxic oxidative damage of the $\mathrm{Na} / \mathrm{K}$-ATPase. Oxidative damage increases $\mathrm{Na} / \mathrm{K}$-ATPase degradation through both the proteasomal and endo-/lysosomal proteolytic pathways [163]. In purified renal $\mathrm{Na} / \mathrm{K}$-ATPase, peroxynitrite $\left(\mathrm{ONOO}^{-}\right)$causes tyrosine nitration and cysteine thiol group modification of the $\mathrm{Na} / \mathrm{K}$ ATPase, but only cysteine thiol group modification is implied in the inhibition of the enzyme activity since glutathione is unable to reverse the inhibition [167]. In isolated rat renal RPTs, peroxynitrite and its signaling participates in Ang IIinduced regulation of renal $\mathrm{Na} / \mathrm{K}$-ATPase activity [168].

Ang II inhibits the $\mathrm{Na} / \mathrm{K}$-ATPase via PKC-dependent NOX activation. The dependence of Ang II-induced Na/KATPase inhibition on NOX and superoxide, as well as reversible oxidative modification of the $\mathrm{Na} / \mathrm{K}$-ATPase, strongly suggests a role for redox signaling [164-166]. In cardiac myocytes and pig kidney, oxidative stress induces glutathionylation of the $\beta 1$ subunit of the $\mathrm{Na} / \mathrm{K}$-ATPase. In purified pig renal $\mathrm{Na} / \mathrm{K}$-ATPase, peroxynitrite inhibits the enzymatic activity by stabilization of the enzyme in an
$\mathrm{E}_{2}$-prone conformation. At the same time, FXYD proteins reverse oxidative stress-induced inhibition of the $\mathrm{Na} / \mathrm{K}$ ATPase by facilitating deglutathionylation of the $\beta 1$ subunit. Moreover, both tyrosine kinase c-Src and cell membrane structural component lipid rafts, which are critical in $\mathrm{Na} / \mathrm{K}-$ ATPase/c-Src signaling, are also critical in redox signaling platform formation [169-172]. These observations, along with the fact that c-Src is redox-sensitive [173] and its activation regulates NOX-derived superoxide generation [174], suggests a redox-sensitive Na/K-ATPase/c-Src signaling cascade and its possible role in ROS regulation, although the mechanism is not clear. Our unpublished data suggest that certain basal levels of ROS might be required for the initiation of ouabain-Na/K-ATPase/c-Src signaling. In LLCPK1 cells, pretreatment with higher concentrations of NAC ( 5 and $10 \mathrm{mM}$ for $30 \mathrm{~min}$ ), but not with lower concentration of $1 \mathrm{mM}$, can prevent ouabain-stimulated c-Src activation and the redistribution of $\mathrm{Na} / \mathrm{K}-\mathrm{ATPase}$ and NHE3. This suggests that ROS may stabilize $\mathrm{Na} / \mathrm{K}$-ATPase in a certain conformational status in order to facilitate ouabain binding to the $\mathrm{Na} / \mathrm{K}$-ATPase $\boldsymbol{\alpha} 1$ subunit and favor ouabain- $\mathrm{Na} / \mathrm{K}$ ATPase/c-Src signaling. Some pertinent questions remain to be resolved, such as how ROS interacts with and influences the $\mathrm{Na} / \mathrm{K}$-ATPase/c-Src signaling cascade and whether ouabain-induced ROS boosts the Na/K-ATPase signaling by a positive feedback mechanism and chronically desensitizes the signaling cascade by stimulating $\mathrm{Na} / \mathrm{K}-\mathrm{ATPase} / \mathrm{c}-\mathrm{Src}$ endocytosis (Figure 2).

\section{Oxidative Stress and Regulation of Renal Function}

ROS function as important intracellular and extracellular second messengers to modulate many signaling molecules. Physiological concentrations of ROS play an important role in normal redox signaling, while pathological levels of ROS contribute to renal and vascular dysfunction and remodeling through oxidative damage [175-177]. Genetic factor(s) partially contribute to high basal ROS levels and the development of hypertension [178, 179].

Oxidative stress has been shown to regulate BP and sodium handling in various animal models. High salt intake increases oxidative stress, and this has important implications for the regulation of cardiovascular and renal systems. An increase in oxidative stress is both a cause and consequence of hypertension [177, 180-183]. Renal NOX is present in the renal cortex, medulla, and vasculature. NOX, the major source of superoxide in the kidney, is of particular interest because of its prominent expression and implication in pathophysiology. In the kidney, increased oxidative stress influences a number of physiologic processes including renal sodium handling in the proximal tubule $[137,168,184,185]$ and thick ascending limb [186], renal medulla blood flow [183, 187-190], descending vasa recta contraction $[191,192]$ in addition to interactions with other regulatory systems such as the dopamine signaling pathway [193]. Increased oxidative stress has been shown to contribute to salt sensitivity [194, 195]. In macula densa cells, NOX isoform 
Nox2 is responsible for salt-induced superoxide generation, while Nox4 regulates basal ROS [196]. In the medullar thick ascending limb of the loop of Henle, both exogenous and endogenous superoxides stimulate sodium absorption [197]. Also, in this nephron segment, NOX-induced generation of superoxide enhances sodium absorption by reduction of the bioavailability of nitric oxide (NO) to prevent NO-induced reduction of $\mathrm{NaCl}$ absorption [198], which contributes to salt-sensitive hypertension observed in Dahl salt-sensitive rats [190].

In PRTs, in particular, increases in ROS inhibit the $\mathrm{Na} / \mathrm{K}$ ATPase as well as the apical NHE3 and sodium/glucose cotransporter, in order to promote RPT sodium excretion under certain circumstances [137, 168, 184, 185]. While elevated basal level of superoxide inhibits proximal tubule NHE3 activity and fluid reabsorption in SHR rats in comparison to WKY rats [137], peroxynitrite and its signaling participates in Ang II-induced regulation of renal $\mathrm{Na} / \mathrm{K}$ ATPase activity in isolated rat renal RPTs [168]. In the pathogenesis of diabetic nephropathy, a high level of glucoseinduced ROS generation induced by stimulation of mitochondrial metabolism and NOX activity in RPT primary cultures leads to inhibition of the expression and activity of the sodium/glucose cotransport system [185]. In male Wistar rats, a high salt diet ( $3 \% \mathrm{NaCl}$ for 2 weeks) promotes sodium/water excretion and urinary 8 -isoprostane excretion, a marker of oxidative stress, which can be attenuated by treatment with apocynin, an NOX inhibitor. The salt loading leads to increased generation of ROS and a state of oxidative stress in the cortex but not to such a degree in the medulla [199].

RPT sodium and/or fluid absorption in the normal rat is reduced by inhibition of NO synthesis, while NO promotes $\mathrm{RPT} \mathrm{Na}^{+}$and/or fluid reabsorption [200]. In immortalized and freshly isolated RPTs from the WKY and SHR rats, the basal level of membrane NOX activity is greater in SHRs [201]. Moreover, NOX-induced superoxide generation inhibits RPT fluid reabsorption in SHRs [137]. In Sprague-Dawley rats treated with the oxidant L-buthionine sulfoximine, Ang II overstimulates RPT Na/K-ATPase and NOX and leads to increased sodium reabsorption, which is prevented by administration of the superoxide scavenger Tempol [202].

High salt diet, which is well documented for its stimulation of systematic oxidative stress, regulates the activity and distribution of the Na/K-ATPase and NHE3 in different animal models [203-207]. PRT sodium reabsorption significantly affects water and sodium homeostasis by regulating redistribution of ion transporters in response to high salt intake [208]. Regulation of NHE3 activity and distribution as well as PRT fluid reabsorption contribute to the development and maintenance of hypertension in young and adult SHR rats $[127,137,209]$.

It has become clear that antioxidant agents such as Tempol and enzymes such as heme oxygenase-1 (HO-1) exhibit a beneficial and protective effect on BP in various animal models of hypertension. As an example, inhibition of $\mathrm{HO}$ activity reduces renal medullary blood flow [84, 210, 211], total renal blood flow (RBF) [212], glomerular filtration rate (GFR), and renal production of nitric oxide [213]. Inhibition of HO-1 increases mean arterial pressure in Sprague-Dawley rats $[214,215]$ and SHR rats [216]. Induction of HO- 1 reduces $\mathrm{BP}$ in SHR rats [217-220]. The effect of HO-1 on BP is presumably through the carbon monoxide $(\mathrm{CO}) / \mathrm{HO}$ system and depression of cytochrome p-450-derived 20-HETE. In the Dahl salt-dependent model of systemic hypertension, induction of HO-1 occurred in the vasculature and is accompanied by endothelial dysfunction [221, 222]. In Dahl salt-sensitive rats, a high salt diet increases $\mathrm{HO}-1$ expression and $\mathrm{CO}$ generation in aorta and coronary arteries [221, 223], and, in Dahl salt-sensitive rats fed low salt diet, induction of HO-1 expression attenuates oxidative stress and reduces proteinuria and renal injury [224]. However, most studies examining the contribution of $\mathrm{HO}-1$ to $\mathrm{BP}$ regulation have focused on the vasculature, that is, pressure-natriuresis and arterial BP, and so the role of HO-1 in RPT-mediated sodium handling is still poorly understood. Nevertheless, increased HO expression in RPTs could result in an increased ability to buffer locally produced oxidants, leading to their neutralization.

The beneficial effect of antioxidants is controversial and not seen in most clinic trials with administration of antioxidants (reviewed in $[177,225]$ ). The Dietary Approaches to Stop Hypertension (DASH) study and subsequent studies have demonstrated that lower BP associated with reduced dietary salt intake may be related to reductions in oxidative stress [6, 226-228]. Interestingly, however, while a combination antioxidant supplement (with an ascorbic acid, synthetic vitamin $\mathrm{E}$, and $\beta$-carotene) had no improvement on BP after 5-year treatment [229], another combination antioxidant supplement (zinc, ascorbic acid, $\alpha$-tocopherol, and $\beta$-carotene) did result in a significant reduction in systolic BP [230]. Other studies have also shown that certain antioxidants, such as glutathione and vitamin $\mathrm{C}$, have a blood-pressure-lowering effect [231, 232]. However, antioxidant supplementation may be ineffective or even dangerous [233] due to the possible "over-antioxidant-buffering" effect of excessive antioxidant supplementation. In this scenario, excess antioxidants might become pro-oxidants (by providing $\mathrm{H}^{+}$) if they cannot promptly be reduced by the following antioxidant in the biological antioxidant chain. Thus, it appears that the balance of the ROS status, within a physiological range, may be more important to maintain beneficial ROS signaling.

\section{Perspective}

Renal sodium handling is a key determinant of blood pressure. ROS status, among others, is an important regulator of vasculature and sodium handling. However, the effect of ROS and $\mathrm{Na} / \mathrm{K}$-ATPase, especially of their interaction, on RPT sodium reabsorption has only been explored in a limited fashion. Coordinated regulation of two major ion transporters, the basolateral $\mathrm{Na} / \mathrm{K}$-ATPase and the apical NHE3, has been implicated in the counterbalancing of high salt intake (volume expansion) mediated blood pressure increase. The $\mathrm{Na} / \mathrm{K}$-ATPase/c-Src signaling regulates this 
coordinated regulatory mechanism and impairment of this signaling cascade contributes to experimental Dahl saltsensitive hypertension. Both the Na/K-ATPase $(\alpha$ and $\beta$ subunit) and its proximal signaling partner $\mathrm{c}-\mathrm{Src}$ are redox sensitive, suggesting a redox-sensitive $\mathrm{Na} / \mathrm{K}$-ATPase/c-Src signaling complex. However, the mechanisms remain largely to be elucidated since the available data is limited [184, 234]. Nevertheless, some pertinent questions remain to be addressed. In the future, it will be important to explore whether ROS signaling is a link between the Na/K-ATPase/cSrc cascade and NHE3 regulation and how oxidative stress stimulated by high salt and CTS regulates $\mathrm{Na} / \mathrm{K}-\mathrm{ATPase} / \mathrm{c}-$ Src signaling in renal sodium handling and fibrosis.

\section{References}

[1] D. A. Calhoun, D. Jones, S. Textor et al., "Resistant hypertension: siagnosis, evaluation, and treatment a scientific statement from the american heart association professional education committee of the council for high blood pressure research," Hypertension, vol. 51, no. 6, pp. 1403-1419, 2008.

[2] F. J. He and G. A. MacGregor, "Effect of longer-term modest salt reduction on blood pressure," Cochrane Database of Systematic Reviews, no. 3, Article ID CD004937, 2004.

[3] A. C. Guyton, "Blood pressure control-special role of the kidneys and body fluids," Science, vol. 252, no. 5014, pp. 1813-1816, 1991.

[4] J. A. Staessen, J. Wang, G. Bianchi, and W. H. Birkenhäger, "Essential hypertension," Lancet, vol. 361, no. 9369, pp. 1629-1641, 2003.

[5] M. H. Weinberger, J. Z. Miller, and F. C. Luft, "Definitions and characteristics of sodium sensitivity and blood pressure resistance," Hypertension, vol. 8, no. 6, pp. II127-II134, 1986.

[6] F. M. Sacks, L. P. Svetkey, W. M. Vollmer et al., "Effects on blood pressure of reduced dietary sodium and the dietary approaches to stop hypertension (DASH) diet," New England Journal of Medicine, vol. 344, no. 1, pp. 3-10, 2001.

[7] L. K. Dahl, M. Heine, and K. Thompson, "Genetic influence of the kidneys on blood pressure. Evidence from chronic renal homografts in rats with opposite predispositions to hypertension," Circulation Research, vol. 40, no. 4, pp. 94101, 1974.

[8] G. Bianchi et al., "The hypertensive role of the kidney in spontaneously hypertensive rats," Clinical Science and Molecular Medicine, vol. 23, no. 45, Supplement 1, pp. S135S139, 1973.

[9] J. Heller, G. Schubert, J. Havlickova, and K. Thurau, "The role of the kidney in the development of hypertension: a transplantation study in the Prague hypertensive rat," Pflugers Archiv European Journal of Physiology, vol. 425, no. 3-4, pp. 208-212, 1993.

[10] D. A. Morgan, G. F. DiBona, and A. L. Mark, "Effects of interstrain renal transplantation of $\mathrm{NaCl}$-induced hypertension in Dahl rats," Hypertension, vol. 15, no. 4, pp. 436-442, 1990.

[11] J. J. Curtis, R. G. Luke, and H. P. Dustan, "Remission of essential hypertension after renal transplantation," New England Journal of Medicine, vol. 309, no. 17, pp. 1009-1015, 1983.

[12] A. Y. Bagrov and J. I. Shapiro, "Endogenous digitalis: pathophysiologic roles and therapeutic applications," Nature Clinical Practice Nephrology, vol. 4, no. 7, pp. 378-392, 2008.
[13] V. M. Buckalew, "Endogenous digitalis-like factors. An historical overview," Frontiers in Bioscience, vol. 10, no. 1, pp. 2325-2334, 2005.

[14] O. V. Fedorova, J. I. Shapiro, and A. Y. Bagrov, "Endogenous cardiotonic steroids and salt-sensitive hypertension," Biochimica et Biophysica Acta, vol. 1802, no. 12, pp. 12301236, 2010.

[15] J. Liu and Z. J. Xie, "The sodium pump and cardiotonic steroids-induced signal transduction protein kinases and calcium-signaling microdomain in regulation of transporter trafficking," Biochimica et Biophysica Acta, vol. 1802, no. 12, pp. 1237-1245, 2010.

[16] W. Schoner and G. Scheiner-Bobis, "Role of endogenous cardiotonic steroids in sodium homeostasis," Nephrology Dialysis Transplantation, vol. 23, no. 9, pp. 2723-2729, 2008.

[17] P. Meneton, X. Jeunemaitre, H. E. De Wardener, and G. A. Macgregor, "Links between dietary salt intake, renal salt handling, blood pressure, and cardiovascular diseases," Physiological Reviews, vol. 85, no. 2, pp. 679-715, 2005.

[18] W. Schoner and G. Scheiner-Bobis, "Endogenous and exogenous cardiac glycosides: their roles in hypertension, salt metabolism, and cell growth," American Journal of Physiology, Cell Physiology, vol. 293, no. 2, pp. C509-C536, 2007.

[19] J. M. Hamlyn, M. P. Blaustein, S. Bova et al., "Identification and characterization of a ouabain-like compound from human plasma," Proceedings of the National Academy of Sciences of the United States of America, vol. 88, no. 14, pp. 6259-6263, 1991.

[20] J. Laredo, J. R. Shah, Z. R. Lu, B. P. Hamilton, and J. M. Hamlyn, "Angiotensin II stimulates secretion of endogenous ouabain from bovine adrenocortical cells via angiotensin type 2 receptors," Hypertension, vol. 29, no. 1, pp. 401-407, 1997.

[21] A. Y. Bagrov, J. I. Shapiro, and O. V. Fedorova, "Endogenous cardiotonic steroids: physiology, pharmacology, and novel therapeutic targets," Pharmacological Reviews, vol. 61, no. 1, pp. 9-38, 2009.

[22] K. J. Sweadner, "Isozymes of the $\mathrm{Na}^{+} / \mathrm{K}^{+}$-ATPase," Biochimica et Biophysica Acta, vol. 988, no. 2, pp. 185-220, 1989.

[23] J. H. Kaplan, "Biochemistry of Na,K-ATPase," Annual Review of Biochemistry, vol. 71, pp. 511-535, 2002.

[24] G. Blanco and R. W. Mercer, "Isozymes of the Na-K-ATPase: heterogeneity in structure, diversity in function," American Journal of Physiology, vol. 275, no. 5, pp. F633-F650, 1998.

[25] G. Sanchez, A. N. T. Nguyen, B. Timmerberg, J. S. Tash, and G. Blanco, "The Na,K-ATPase $\alpha 4$ isoform from humans has distinct enzymatic properties and is important for sperm motility," Molecular Human Reproduction, vol. 12, no. 9, pp. 565-576, 2006.

[26] S. P. Barwe, G. Anilkumar, S. Y. Moon et al., "Novel role for $\mathrm{Na}, \mathrm{K}$-ATPase in phosphatidylinositol 3-kinase signaling and suppression of cell motility," Molecular Biology of the Cell, vol. 16, no. 3, pp. 1082-1094, 2005.

[27] A. T. Beggah and K. Geering, " $\alpha$ and $\beta$ subunits of Na,KATPase interact with BiP and calnexin," Annals of the New York Academy of Sciences, vol. 834, pp. 537-539, 1997.

[28] M. S. Feschenko, R. K. Wetzel, and K. J. Sweadner, "Phosphorylation of Na,K-ATPase by protein kinases. Sites, susceptibility, and consequences," Annals of the New York Academy of Sciences, vol. 834, pp. 479-488, 1997.

[29] C. Jordan, B. Püschel, R. Koob, and D. Drenckhahn, "Identification of a binding motif for ankyrin on the $\alpha$-subunit of $\mathrm{Na}^{+}, \mathrm{K}^{+}$-ATPase," Journal of Biological Chemistry, vol. 270, no. 50, pp. 29971-29975, 1995. 
[30] K. Lee, J. Jung, M. Kim, and G. Guidotti, "Interaction of the $\alpha$ subunit of Na,K-ATPase with, cofilin," Biochemical Journal, vol. 353, no. 2, pp. 377-385, 2001.

[31] J. Tian, T. Cai, Z. Yuan et al., "Binding of Src to $\mathrm{Na}^{+} / \mathrm{K}^{+}$ATPase forms a functional signaling complex," Molecular Biology of the Cell, vol. 17, no. 1, pp. 317-326, 2006.

[32] Z. Xie and T. Cai, "Na+-K+-ATPase-mediated signal transduction: from protein interaction to cellular function," Mol Interv, vol. 3, no. 3, pp. 157-168, 2003.

[33] G. A. Yudowski, R. Efendiev, C. H. Pedemonte, A. I. Katz, P. O. Berggren, and A. M. Bertorello, "Phosphoinositide-3 kinase binds to a proline-rich motif in the $\mathrm{Na}^{+}, \mathrm{K}^{+}$-ATPase $\alpha$ subunit and regulates its trafficking," Proceedings of the National Academy of Sciences of the United States of America, vol. 97, no. 12, pp. 6556-6561, 2000.

[34] Z. Zhang, P. Devarajan, A. L. Dorfman, and J. S. Morrow, "Structure of the ankyrin-binding domain of $\alpha-\mathrm{Na}, \mathrm{K}$ ATPase," Journal of Biological Chemistry, vol. 273, no. 30, pp. 18681-18684, 1998.

[35] H. Song, M. Y. Lee, S. P. Kinsey, D. J. Weber, and M. P. Blaustein, "An N-terminal sequence targets and tethers $\mathrm{Na}+$ pump $\alpha 2$ subunits to specialized plasma membrane microdomains," Journal of Biological Chemistry, vol. 281, no. 18, pp. 12929-12940, 2006.

[36] S. Zhang, S. Malmersjö, J. Li et al., "Distinct role of the Nterminal tail of the Na,K-ATPase catalytic subunit as a signal transducer," Journal of Biological Chemistry, vol. 281, no. 31, pp. 21954-21962, 2006.

[37] J. H. Kaplan, "A moving new role for the sodium pump in epithelial cells and carcinomas," Science's STKE, vol. 2005, no. 289, p. pe31, 2005.

[38] J. D. Kaunitz, "Membrane transport proteins: not just for transport anymore," American Journal of Physiology, vol. 290, no. 5, pp. F995-F996, 2006.

[39] Z. Li and Z. Xie, "The Na/K-ATPase/Src complex and cardiotonic steroid-activated protein kinase cascades," Pflugers Archiv European Journal of Physiology, vol. 457, no. 3, pp. 635-644, 2009.

[40] O. Aizman, P. Uhlén, M. Lal, H. Brismar, and A. Aperia, "Ouabain, a steroid hormone that signals with slow calcium oscillations," Proceedings of the National Academy of Sciences of the United States of America, vol. 98, no. 23, pp. 1342013424, 2001.

[41] A. Aydemir-Koksoy, J. Abramowitz, and J. C. Allen, "Ouabain-induced signaling and vascular smooth muscle cell proliferation," Journal of Biological Chemistry, vol. 276, no. 49, pp. 46605-46611, 2001.

[42] J. Li, S. Zelenin, A. Aperia, and O. Aizman, "Low doses of ouabain protect from serum deprivation-triggered apoptosis and stimulate kidney cell proliferation via activation of NF$\kappa \mathrm{B}$," Journal of the American Society of Nephrology, vol. 17, no. 7, pp. 1848-1857, 2006.

[43] R. Saunders and G. Scheiner-Bobis, "Ouabain stimulates endothelin release and expression in human endothelial cells without inhibiting the sodium pump," European Journal of Biochemistry, vol. 271, no. 5, pp. 1054-1062, 2004.

[44] O. Kotova, L. Al-Khalili, S. Talia et al., "Cardiotonic steroids stimulate glycogen synthesis in human skeletal muscle cells via a Src- and ERK1/2-dependent mechanism," Journal of Biological Chemistry, vol. 281, no. 29, pp. 20085-20094, 2006.

[45] S. J. Khundmiri, M. A. Metzler, M. Ameen, V. Amin, M. J. Rane, and N. A. Delamere, "Ouabain induces cell proliferation through calcium-dependent phosphorylation of Akt (protein kinase B) in opossum kidney proximal tubule cells," American Journal of Physiology, Cell Physiology, vol. 291, no. 6, pp. C1247-C1257, 2006.

[46] L. Trevisi, B. Visentin, F. Cusinato, I. Pighin, and S. Luciani, "Antiapoptotic effect of ouabain on human umbilical vein endothelial cells," Biochemical and Biophysical Research Communications, vol. 321, no. 3, pp. 716-721, 2004.

[47] P. Ferrari, M. Ferrandi, G. Valentini, P. Manunta, and G. Bianchi, "Targeting Ouabain- and Adducin-dependent mechanisms of hypertension and cardiovascular remodeling as a novel pharmacological approach," Medical Hypotheses, vol. 68, no. 6, pp. 1307-1314, 2007.

[48] W. C. Golden and L. J. Martin, "Low-dose ouabain protects against excitotoxic apoptosis and up-regulates nuclear Bcl-2 in vivo," Neuroscience, vol. 137, no. 1, pp. 133-144, 2006.

[49] X. Jiang, Y. P. Ren, and Z. R. Lü, "Ouabain induces cardiac remodeling in rats independent of blood pressure," Acta Pharmacologica Sinica, vol. 28, no. 3, pp. 344-352, 2007.

[50] M. Li, Q. Wang, and L. Guan, "Effects of ouabain on proliferation, intracellular free calcium and c-myc mRNA expression in vascular smooth muscle cells," Journal of Comparative Physiology B, vol. 177, no. 5, pp. 589-595, 2007.

[51] R. Skoumal, I. Szokodi, J. Aro et al., "Involvement of endogenous ouabain-like compound in the cardiac hypertrophic process in vivo," Life Sciences, vol. 80, no. 14, pp. 1303-1310, 2007.

[52] K. Taguchi, H. Kumanogoh, S. Nakamura, and S. Maekawa, "Ouabain-induced isoform-specific localization change of the $\mathrm{Na}^{+}, \mathrm{K}^{+}$-ATPase $\alpha$ subunit in the synaptic plasma membrane of rat brain," Neuroscience Letters, vol. 413, no. 1, pp. 42-45, 2007.

[53] J. C. Thundathil, M. Anzar, and M. M. Buhr, " $\mathrm{Na}^{+} / \mathrm{K}^{+}$ATPase as a signaling molecule during bovine sperm capacitation," Biology of Reproduction, vol. 75, no. 3, pp. 308-317, 2006.

[54] I. Larre, A. Ponce, R. Fiorentino, L. Shoshani, R. G. Contreras, and M. Cereijido, "Contacts and cooperation between cells depend on the hormone ouabain," Proceedings of the National Academy of Sciences of the United States of America, vol. 103, no. 29, pp. 10911-10916, 2006.

[55] A. N. T. Nguyen, D. P. Wallace, and G. Blanco, "Ouabain binds with high affinity to the Na,K-ATPase in human polycystic kidney cells and induces extracellular signalregulated kinase activation and cell proliferation," Journal of the American Society of Nephrology, vol. 18, no. 1, pp. 46-57, 2007.

[56] R. L. Dmitrieva and P. A. Doris, "Ouabain is a potent promoter of growth and activator of ERK1/2 in ouabainresistant rat renal epithelial cells," Journal of Biological Chemistry, vol. 278, no. 30, pp. 28160-28166, 2003.

[57] I. Larre, A. Lazaro, R. G. Contreras et al., "Ouabain modulates epithelial cell tight junction," Proceedings of the National Academy of Sciences of the United States of America, vol. 107, no. 25, pp. 11387-11392, 2010.

[58] A. K. Rajasekaran and S. A. Rajasekaran, "Role of Na-KATPase in the assembly of tight junctions," American Journal of Physiology, vol. 285, no. 3, pp. F388-F396, 2003.

[59] M. P. Blaustein, J. Zhang, L. Chen et al., "The pump, the exchanger, and endogenous ouabain: signaling mechanisms that link salt retention to hypertension," Hypertension, vol. 53, no. 2, pp. 291-298, 2009.

[60] A. Y. Bagrov and O. V. Fedorova, "Cardenolide and bufadienolide ligands of the sodium pump. How they work together in $\mathrm{NaCl}$ sensitive hypertension," Frontiers in Bioscience, vol. 10, no. 1, pp. 2250-2256, 2005. 
[61] A. M. Bertorello and J. I. Sznajder, "The dopamine paradox in lung and kidney epithelia: sharing the same target but operating different signaling networks," American Journal of Respiratory Cell and Molecular Biology, vol. 33, no. 5, pp. 432437, 2005.

[62] J. Liu and J. I. Shapiro, "Regulation of sodium pump endocytosis by cardiotonic steroids: molecular mechanisms and physiological implications," Pathophysiology, vol. 14, no. 3-4, pp. 171-181, 2007.

[63] Z. Xie and A. Askari, "Na ${ }^{+} / \mathrm{K}^{+}$-ATPase as a signal transducer," European Journal of Biochemistry, vol. 269, no. 10, pp. 2434 2439, 2002.

[64] A. Aperia, "New roles for an old enzyme: Na,K-ATPase emerges as an interesting drug target," Journal of Internal Medicine, vol. 261, no. 1, pp. 44-52, 2007.

[65] R. A. Kelly and T. W. Smith, "The search for the endogenous digitalis: an alternative hypothesis," American Journal of Physiology, vol. 256, no. 5, pp. C937-C950, 1989.

[66] R. Foulkes, R. G. Ferrario, P. Salvati, and G. Bianchi, "Differences in ouabain-induced natriuresis between isolated kidneys of Milan hypertensive and normotensive rats," Clinical Science, vol. 82, no. 2, pp. 185-190, 1992.

[67] N. A. Yates and J. G. McDougall, "Effect of volume expansion on the natriuretic response to ouabain infusion," Renal Physiology and Biochemistry, vol. 18, no. 6, pp. 311-320, 1995.

[68] I. Dostanic-Larson, J. W. van Huysse, J. N. Lorenz, and J. B. Lingrel, "The highly conserved cardiac glycoside binding site of $\mathrm{Na}, \mathrm{K}-\mathrm{ATP}$ ase plays a role in blood pressure regulation," Proceedings of the National Academy of Sciences of the United States of America, vol. 102, no. 44, pp. 15845-15850, 2005.

[69] E. L. Loreaux, B. Kaul, J. N. Lorenz, and J. B. Lingrel, "Ouabain-sensitive $\alpha 1 \mathrm{Na}, \mathrm{K}$-ATPase enhances natriuretic response to saline load," Journal of the American Society of Nephrology, vol. 19, no. 10, pp. 1947-1954, 2008.

[70] M. Nesher, M. Dvela, V. U. Igbokwe, H. Rosen, and D. Lichtstein, "Physiological roles of endogenous ouabain in normal rats," American Journal of Physiology, Heart and Circulatory Physiology, vol. 297, no. 6, pp. H2026-H2034, 2009.

[71] O. V. Fedorova, N. I. Kolodkin, N. I. Agalakova, E. G. Lakatta, and A. Y. Bagrov, "Marinobufagenin, an endogenous $\alpha$ 1 sodium pump ligand, in hypertensive Dahl salt-sensitive rats," Hypertension, vol. 37, no. 2, pp. 462-466, 2001.

[72] O. V. Fedorova, M. I. Talan, N. I. Agalakova, E. G. Lakatta, and A. Y. Bagrov, "Endogenous ligand of $\alpha 1$ sodium pump, marinobufagenin, is a novel mediator of sodium chloridedependent hypertension," Circulation, vol. 105, no. 9, pp. 1122-1127, 2002.

[73] D. E. Anderson, O. V. Fedorova, C. H. Morrell et al., "Endogenous sodium pump inhibitors and age-associated increases in salt sensitivity of blood pressure in normotensives," American Journal of Physiology, Regulatory Integrative and Comparative Physiology, vol. 294, no. 4, pp. R1248-R1254, 2008.

[74] P. Manunta, P. Stella, R. Rivera et al., "Left ventricular mass, stroke volume, and ouabain-like factor in essential hypertension," Hypertension, vol. 34, no. 3, pp. 450-456, 1999.

[75] P. Manunta, B. P. Hamilton, and J. M. Hamlyn, "Salt intake and depletion increase circulating levels of endogenous ouabain in normal men," American Journal of Physiology, Regulatory Integrative and Comparative Physiology, vol. 290, no. 3, pp. R553-R559, 2006.
[76] B. S. Huang, M. S. Amin, and F. H. H. Leenen, "The central role of the brain in salt-sensitive hypertension," Current Opinion in Cardiology, vol. 21, no. 4, pp. 295-304, 2006.

[77] J. W. van Huysse, "Endogenous brain Na pumps, brain ouabain-like substance and the $\alpha 2$ isoform in salt-dependent hypertension," Pathophysiology, vol. 14, no. 3-4, pp. 213-220, 2007.

[78] O. V. Fedorova, I. A. Zhuravin, N. I. Agalakova et al., "Intrahippocampal microinjection of an exquisitely low dose of ouabain mimics $\mathrm{NaCl}$ loading and stimulates a bufadienolide $\mathrm{Na} / \mathrm{K}$-ATPase inhibitor," Journal of Hypertension, vol. 25, no. 9, pp. 1834-1844, 2007.

[79] O. V. Fedorova, N. I. Agalakova, M. I. Talan, E. G. Lakatta, and A. Y. Bagrov, "Brain ouabain stimulates peripheral marinobufagenin via angiotensin II signalling in $\mathrm{NaCl}-$ loaded Dahl-S rats," Journal of Hypertension, vol. 23, no. 8, pp. 1515-1523, 2005.

[80] D. J. Kennedy, S. Vetteth, S. M. Periyasamy et al., "Central role for the cardiotonic steroid marinobufagenin in the pathogenesis of experimental uremic cardiomyopathy," Hypertension, vol. 47, no. 3, pp. 488-495, 2006.

[81] M. Ferrandi, I. Molinari, P. Barassi, E. Minotti, G. Bianchi, and P. Ferrari, "Organ hypertrophic signaling within caveolae membrane subdomains triggered by ouabain and antagonized by PST 2238," Journal of Biological Chemistry, vol. 279, no. 32, pp. 33306-33314, 2004.

[82] J. Liu, J. Tian, M. Haas, J. I. Shapiro, A. Askari, and Z. Xie, "Ouabain interaction with cardiac $\mathrm{Na}^{+} / \mathrm{K}^{+}$-ATPase initiates signal cascades independent of changes in intracellular $\mathrm{Na}^{+}$ and $\mathrm{Ca}^{2+}$ concentrations," Journal of Biological Chemistry, vol. 275, no. 36, pp. 27838-27844, 2000.

[83] S. Priyadarshi, B. Valentine, C. Han et al., "Effect of green tea extract on cardiac hypertrophy following 5/6 nephrectomy in the rat," Kidney International, vol. 63, no. 5, pp. 1785-1790, 2003.

[84] J. Elkareh, D. J. Kennedy, B. Yashaswi et al., "Marinobufagenin stimulates fibroblast collagen production and causes fibrosis in experimental uremic cardiomyopathy," Hypertension, vol. 49, no. 1, pp. 215-224, 2007.

[85] D. J. Kennedy, J. Elkareh, A. Shidyak et al., "Partial nephrectomy as a model for uremic cardiomyopathy in the mouse," American Journal of Physiology, vol. 294, no. 2, pp. F450F454, 2008.

[86] J. Elkareh, S. M. Periyasamy, A. Shidyak et al., "Marinobufagenin induces increases in procollagen expression in a process involving protein kinase $\mathrm{C}$ and Fli-1: implications for uremic cardiomyopathy," American Journal of Physiology, vol. 296, no. 5, pp. F1219-F1226, 2009.

[87] J. Tian, A. Shidyak, S. M. Periyasamy et al., "Spironolactone attenuates experimental uremic cardiomyopathy by antagonizing marinobufagenin," Hypertension, vol. 54, no. 6, pp. 1313-1320, 2009.

[88] N. El-Okdi, S. Smaili, V. Raju et al., "Effects of cardiotonic steroids on dermal collagen synthesis and wound healing," Journal of Applied Physiology, vol. 105, no. 1, pp. 30-36, 2008.

[89] L. V. Fedorova, V. Raju, N. El-Okdi et al., "The cardiotonic steroid hormone marinobufagenin induces renal fibrosis: implication of epithelial-to-mesenchymal transition," American Journal of Physiology, vol. 296, no. 4, pp. F922-F934, 2009.

[90] M. P. Blaustein, "Sodium ions, calcium ions, blood pressure regulation, and hypertension: a reassessment and a hypothesis," American Journal of Physiology, Cell Physiology, vol. 232, no. 5, pp. C165-C173, 1977. 
[91] F. J. Haddy, M. B. Pamnani, and D. L. Clough, "Humoral factors and the sodium-potassium pump in volume expanded hypertension," Life Sciences, vol. 24, no. 23, pp. 2105-2117, 1979.

[92] H. E. de Wardener and E. M. Clarkson, "Concept of natriuretic hormone," Physiological Reviews, vol. 65, no. 3, pp. 658-759, 1985.

[93] F. J. Haddy and H. W. Overbeck, "The role of humoral agents in volume expanded hypertension," Life Sciences, vol. 19, no. 7, pp. 935-947, 1976.

[94] H. E. de Wardener and E. M. Clarkson, "Concept of natriuretic hormone," Physiological Reviews, vol. 65, no. 3, pp. 658-759, 1985.

[95] J. G. McDougall and N. A. Yates, "Natriuresis and inhibition of $\mathrm{Na}^{+} / \mathrm{K}^{+}$-ATPase: modulation of response by physiological manipulation," Clinical and Experimental Pharmacology and Physiology, vol. 25, supplement, pp. S57-S60, 1998.

[96] N. A. Yates and J. G. McDougall, "Effects of direct renal arterial infusion of bufalin and ouabain in conscious sheep," British Journal of Pharmacology, vol. 108, no. 3, pp. 627-630, 1993.

[97] N. A. Yates and J. G. McDougall, "Interaction of exogenous ouabain and chronic mineralocorticoid treatment in the kidney of the conscious sheep," Clinical and Experimental Pharmacology and Physiology, vol. 24, no. 1, pp. 57-63, 1997.

[98] H. E. de Wardener and G. A. MacGregor, "Dahl's hypothesis that a saluretic substance may be responsible for a sustained rise in arterial pressure: its possible role in essential hypertension," Kidney International, vol. 18, no. 1, pp. 1-9, 1980.

[99] O. V. Fedorova, N. I. Agalakova, C. H. Morrell, E. G. Lakatta, and A. Y. Bagrov, "ANP differentially modulates marinobufagenin-induced sodium pump inhibition in kidney and aorta," Hypertension, vol. 48, no. 6, pp. 1160-1168, 2006.

[100] O. V. Fedorova, E. G. Lakatta, and A. Y. Bagrov, "Endogenous $\mathrm{Na}, \mathrm{K}$ pump ligands are differentially regulated during acute $\mathrm{NaCl}$ loading of dahl rats," Circulation, vol. 102, no. 24, pp. 3009-3014, 2000.

[101] W. Schoner and G. Scheiner-Bobis, "Role of endogenous cardiotonic steroids in sodium homeostasis," Nephrology Dialysis Transplantation, vol. 23, no. 9, pp. 2723-2729, 2008.

[102] M. Yoshika, Y. Komiyama, M. Konishi et al., "Novel digitalislike factor, marinobufotoxin, isolated from cultured Y-1 cells, and its hypertensive effect in rats," Hypertension, vol. 49, no. 1, pp. 209-214, 2007.

[103] E. Ritz et al., "Uremic Cardiomyopathy-An Endogenous Digitalis Intoxication?" Journal of the American Society of Nephrology, vol. 17, no. 6, pp. 1493-1497, 2006.

[104] A. Y. Bagrov, J. I. Shapiro, and O. V. Fedorova, "Endogenous cardiotonic steroids: physiology, pharmacology, and novel therapeutic targets," Pharmacological Reviews, vol. 61, no. 1, pp. 9-38, 2009.

[105] F. J. Haddy and M. B. Pamnani, "Role of ouabain-like factors and NA-K-ATPase inhibitors in hypertension—some old and recent findings," Clinical and Experimental Hypertension, vol. 20, no. 5-6, pp. 499-508, 1998.

[106] W. Schoner and G. Scheiner-Bobis, "Endogenous and exogenous cardiac glycosides: their roles in hypertension, salt metabolism, and cell growth," American Journal of Physiology, Cell Physiology, vol. 293, no. 2, pp. C509-C536, 2007.

[107] J. Tian, S. Haller, S. Periyasamy et al., "Renal ischemia regulates marinobufagenin release in humans," Hypertension, vol. 56, no. 5, pp. 914-919, 2010.
[108] H. Cai, L. Wu, W. Qu et al., "Regulation of apical NHE3 trafficking by ouabain-induced activation of the basolateral $\mathrm{Na}^{+}, \mathrm{K}^{+}$-ATPase receptor complex," American Journal of Physiology, Cell Physiology, vol. 294, no. 2, pp. C555-C563, 2008.

[109] J. Liu, R. Kesiry, S. M. Periyasamy, D. Malhotra, Z. Xie, and J. I. Shapiro, "Ouabain induces endocytosis of plasmalemmal $\mathrm{Na} / \mathrm{K}-\mathrm{ATPase}$ in LLC-PK1 cells by a clathrin-dependent mechanism," Kidney International, vol. 66, no. 1, pp. 227241, 2004.

[110] J. Liu, M. Liang, L. Liu, D. Malhotra, Z. Xie, and J. I. Shapiro, "Ouabain-induced endocytosis of the plasmalemmal Na/KATPase in LLC-PK1 cells requires caveolin-1," Kidney International, vol. 67, no. 5, pp. 1844-1854, 2005.

[111] J. Liu, S. M. Periyasamy, W. Gunning et al., "Effects of cardiac glycosides on sodium pump expression and function in LLCPK1 and MDCK cells," Kidney International, vol. 62, no. 6, pp. 2118-2125, 2002.

[112] S. Oweis, L. Wu, P. R. Kiela et al., "Cardiac glycoside downregulates NHE3 activity and expression in LLC-PK 1 cells," American Journal of Physiology, vol. 290, no. 5, pp. F997-F1008, 2006.

[113] S. M. Periyasamy, J. Liu, F. Tanta et al., "Salt loading induces redistribution of the plasmalemmal $\mathrm{Na} / \mathrm{K}$-ATPase in proximal tubule cells," Kidney International, vol. 67, no. 5, pp. 1868-1877, 2005.

[114] J. Liu, Y. Yan, L. Liu et al., "Impairment of Na/K-ATPase signaling in renal proximal tubule contributes to Dahl saltsensitive hypertension," Journal of Biological Chemistry, vol. 286, no. 26, pp. 22806-22813, 2011.

[115] L. K. Dahl, M. Heine, and L. Tassinari, "Role of genetic factors in susceptibility to experimental hypertension due to chronic excess salt ingestion," Nature, vol. 194, no. 4827, pp. 480-482, 1962.

[116] L. K. Dahl, K. D. Knudsen, and J. Iwai, "Humoral transmission of hypertension: evidence from parabiosis," Circulation Research, vol. 24, no. 5, supplement, pp. 21-33, 1969.

[117] J. P. Rapp, "Dahl salt-susceptible and salt-resistant rats. A review," Hypertension, vol. 4, no. 6, pp. 753-763, 1982.

[118] J. P. Rapp and H. Dene, "Development and characteristics of inbred strains of Dahl salt-sensitive and salt-resistant rats," Hypertension, vol. 7, no. 3, pp. 340-349, 1985.

[119] M. Mokry and E. Cuppen, "The Atplal gene from inbred Dahl salt sensitive rats does not contain the A1079T missense transversion," Hypertension, vol. 51, no. 4, pp. 922-927, 2008.

[120] Y. Yamori, "The development of Spontaneously Hypertensive Rat (SHR) and of various spontaneous rat models, and their implications," in Experimental and Genetic Models of Hypertension, D. Ganten and W. de Jong, Eds., vol. 4 of Handbook of Hypertension, pp. 224-239, Elsevier, New York, NY, USA, 1984.

[121] C. R. Pace-Asciak and M. C. Carrara, "Reduction in dietary vitamin $\mathrm{E}$ prevents onset of hypertension in developing spontaneously hypertensive rats," Experientia, vol. 35, no. 12, pp. 1561-1562, 1979.

[122] J. B. Young, D. Mullen, and L. Landsberg, "Caloric restriction lowers blood pressure in the spontaneously hypertensive rat," Metabolism, vol. 27, no. 12, pp. 1711-1714, 1978.

[123] N. Adams and D. A. Blizard, "Genetic and maternal influences in rat models of spontaneous and salt-induced hypertension," Developmental Psychobiology, vol. 24, no. 7, pp. 507-519, 1991. 
[124] W. J. Arendshorst and W. H. Beierwaltes, "Renal tubular reabsorption in spontaneously hypertensive rats," The American Journal of Physiology, vol. 237, no. 1, pp. F38-47, 1979.

[125] W. H. Beierwaltes and W. J. Arendshorst, "Renal function of conscious spontaneously hypertensive rats," Circulation Research, vol. 42, no. 5, pp. 721-726, 1978.

[126] W. J. Arendshorst, "Autoregulation of renal blood flow in spontaneously hypertensive rats," Circulation Research, vol. 44, no. 3, pp. 344-349, 1979.

[127] R. O. Crajoinas, L. M. A. Lessa, L. R. Carraro-Lacroix et al., "Posttranslational mechanisms associated with reduced NHE3 activity in adult vs. young prehypertensive SHR," American Journal of Physiology, vol. 299, no. 4, pp. F872F881, 2010.

[128] M. S. LaPointe, C. Sodhi, A. Sahai, and D. Batlle, " $\mathrm{Na}^{+} / \mathrm{H}^{+}$ exchange activity and NHE-3 expression in renal tubules from the spontaneously hypertensive rat," Kidney International, vol. 62, no. 1, pp. 157-165, 2002.

[129] L. C. Garg, N. Narang, and S. McArdle, "Na-K-ATPase in nephron segments of rats developing spontaneous hypertension," The American Journal of Physiology, vol. 249, no. 6, pp. F863-869, 1985.

[130] J. L. Cangiano, C. Rodriguez-Sargent, S. Opava-Stitzer, and M. Martinez-Maldonado, "Renal $\mathrm{Na}^{+}, \mathrm{K}^{+}$-ATPase in weanling and adult spontaneously hypertensive rats," Proceedings of the Society for Experimental Biology and Medicine, vol. 177, no. 2, pp. 240-246, 1984.

[131] L. C. Garg and N. Narang, "Differences in renal tubular NaK-adenosine triphosphatase in spontaneously hypertensive and normotensive rats," Journal of Cardiovascular Pharmacology, vol. 8, no. 1, pp. 186-189, 1986.

[132] L. C. Garg and N. Narang, "Effects of hydrochlorothiazide on Na-K-ATPase activity along the rat nephron," Kidney International, vol. 31, no. 4, pp. 918-922, 1987.

[133] G. A. Morduchowicz, D. Sheikh-Hamad, O. D. Jo, E. P. Nord, D. B. N. Lee, and N. Yanagawa, "Increased $\mathrm{Na}+\mathrm{H}+$ antiport activity in the renal brush border membrane of SHR," Kidney International, vol. 36, no. 4, pp. 576-581, 1989.

[134] A. L. Hayward, C. A. Hinojos, B. Nurowska et al., "Altered sodium pump alpha and gamma subunit gene expression in nephron segments from hypertensive rats," Journal of Hypertension, vol. 17, no. 8, pp. 1081-1087, 1999.

[135] J. I. Kourie, "Interaction of reactive oxygen species with ion transport mechanisms," American Journal of Physiology, Cell Physiology, vol. 275, no. 1, pp. C1-C24, 1998.

[136] T. Chabrashvili, A. Tojo, M. L. Onozato et al., "Expression and cellular localization of classic NADPH oxidase subunits in the spontaneously hypertensive rat kidney," Hypertension, vol. 39, no. 2, pp. 269-274, 2002.

[137] C. Panico, Z. Luo, S. Damiano, F. Artigiano, P. Gill, and W. J. Welch, "Renal proximal tubular reabsorption is reduced in adult spontaneously hypertensive rats: roles of superoxide and $\mathrm{Na}^{+} / \mathrm{H}^{+}$exchanger 3," Hypertension, vol. 54, no. 6, pp. 1291-1297, 2009.

[138] A. A. Banday and M. F. Lokhandwala, "Angiotensin IImediated biphasic regulation of proximal tubular $\mathrm{Na}^{+} / \mathrm{H}^{+}$ exchanger 3 is impaired during oxidative stress," American Journal of Physiology, Renal Physiology, vol. 301, no. 2, pp. F364-F370, 2011.

[139] L. A. Dada, E. Novoa, E. Lecuona, H. Sun, and J. I. Sznajder, "Role of the small GTPase RhoA in the hypoxia-induced decrease of plasma membrane Na,K-ATPase in A549 cells," Journal of Cell Science, vol. 120, no. 13, pp. 2214-2222, 2007.
[140] L. Liu, J. Li, J. Liu et al., "Involvement of $\mathrm{Na}^{+} / \mathrm{K}^{+}$ATPase in hydrogen peroxide-induced hypertrophy in cardiac myocytes," Free Radical Biology and Medicine, vol. 41, no. 10, pp. 1548-1556, 2006.

[141] Z. Xie, P. Kometiani, J. Liu, J. Li, J. I. Shapiro, and A. Askari, "Intracellular reactive oxygen species mediate the linkage of $\mathrm{Na}^{+} / \mathrm{K}^{+}$- ATPase to hypertrophy and its marker genes in cardiac myocytes," Journal of Biological Chemistry, vol. 274, no. 27, pp. 19323-19328, 1999.

[142] J. Tian, J. Liu, K. D. Garlid, J. I. Shapiro, and Z. Xie, "Involvement of mitogen-activated protein kinases and reactive oxygen species in the inotropic action of ouabain on cardiac myocytes. A potential role for mitochondrial KATP channels," Molecular and Cellular Biochemistry, vol. 242, no. 1-2, pp. 181-187, 2003.

[143] A. Miyakawa-Naito, P. Uhlén, M. Lal et al., "Cell signaling microdomain with Na,K-ATPase and inositol 1,4,5trisphosphate receptor generates calcium oscillations," Journal of Biological Chemistry, vol. 278, no. 50, pp. 50355-50361, 2003.

[144] M. Kajikawa, S. Fujimoto, Y. Tsuura et al., "Ouabain suppresses glucose-induced mitochondrial ATP production and insulin release by generating reactive oxygen species in pancreatic islets," Diabetes, vol. 51, no. 8, pp. 2522-2529, 2002.

[145] Y. T. Huang, S. C. Chueh, C. M. Teng, and J. H. Guh, "Investigation of ouabain-induced anticancer effect in human androgen-independent prostate cancer PC-3 cells," Biochemical Pharmacology, vol. 67, no. 4, pp. 727-733, 2004.

[146] A. Boldyrev, E. Bulygina, M. Yuneva, and W. Schoner, "Na/K-ATPase regulates intracellular ROS level in cerebellum neurons," Annals of the New York Academy of Sciences, vol. 986, pp. 519-521, 2003.

[147] D. J. Kennedy, S. Vetteth, M. Xie et al., "Ouabain decreases sarco(endo)plasmic reticulum calcium ATPase activity in rat hearts by a process involving protein oxidation," American Journal of Physiology, Heart and Circulatory Physiology, vol. 291, no. 6, pp. H3003-H3011, 2006.

[148] I. M. Glynn, ““Transport adenosinetriphosphatase” in electric organ. The relation between ion transport and oxidative phosphorylation," The Journal of Physiology, vol. 169, no. 2, pp. 452-465, 1963.

[149] M. J. McKenna, I. Medved, C. A. Goodman et al., "Nacetylcysteine attenuates the decline in muscle $\mathrm{Na}^{+}, \mathrm{K}^{+}$pump activity and delays fatigue during prolonged exercise in humans," Journal of Physiology, vol. 576, no. 1, pp. 279288, 2006.

[150] A. Boldyrev and E. Kurella, "Mechanism of oxidative damage of dog kidney Na/K-ATPase," Biochemical and Biophysical Research Communications, vol. 222, no. 2, pp. 483-487, 1996.

[151] D. Dobrota, M. Matejovicova, E. G. Kurella, and A. A. Boldyrev, "Na/K-ATPase under oxidative stress: molecular mechanisms of injury," Cellular and Molecular Neurobiology, vol. 19, no. 1, pp. 141-149, 1999.

[152] E. G. Kurella, O. V. Tyulina, and A. A. Boldyrev, "Oxidative resistance of Na/K-ATPase," Cellular and Molecular Neurobiology, vol. 19, no. 1, pp. 133-140, 1999.

[153] I. Petrushanko, N. Bogdanov, E. Bulygina et al., "Na-KATPase in rat cerebellar granule cells is redox sensitive," American Journal of Physiology, Regulatory Integrative and Comparative Physiology, vol. 290, no. 4, pp. R916-R925, 2006. 
[154] A. Bogdanova, A. Boldyrev, and M. Gassmann, "Oxygenand redox-induced regulaton of the $\mathrm{Na} / \mathrm{K}$ ATPase," Current Enzyme Inhibition, vol. 2, no. 1, pp. 37-59, 2006.

[155] D. Z. Ellis, J. Rabe, and K. J. Sweadner, "Global loss of $\mathrm{Na}, \mathrm{K}$-ATPase and its nitric oxide-mediated regulation in a transgenic mouse model of amyotrophic lateral sclerosis," Journal of Neuroscience, vol. 23, no. 1, pp. 43-51, 2003.

[156] M. S. Kim and T. Akera, " $\mathrm{O}_{2}$ free radicals: cause of ischemiareperfusion injury to cardiac $\mathrm{Na}^{+}, \mathrm{K}^{+}$-ATPase," American Journal of Physiology, Heart and Circulatory Physiology, vol. 252, no. 2, pp. H252-H257, 1987.

[157] Z. Xie, Y. Wang, A. Askari, W. H. Huang, J. E. Klaunig, and A. Askari, "Studies on the specificity of the effects of oxygen metabolites on cardiac sodium pump," Journal of Molecular and Cellular Cardiology, vol. 22, no. 8, pp. 911-920, 1990.

[158] W. H. Huang, Y. Wang, and A. Askari, " $\left(\mathrm{Na}^{+}+\mathrm{K}^{+}\right)$-ATPase: inactivation and degradation induced by oxygen radicals," International Journal of Biochemistry, vol. 24, no. 4, pp. 621626, 1992.

[159] W.-H. Huang, Y. Wang, A. Askari, N. Zolotarjova, and M. Ganjeizadeh, "Different sensitivities of the $\mathrm{Na}^{+} / \mathrm{K}^{+}$ATPase isoforms to oxidants," Biochimica et Biophysica Acta, Biomembranes, vol. 1190, no. 1, pp. 108-114, 1994.

[160] N. Zolotarjova, C. Ho, R. L. Mellgren, A. Askari, and W. -H. Huang, "Different sensitivities of native and oxidized forms of $\mathrm{Na}^{+} / \mathrm{K}^{+}$-ATPase to intracellular proteinases," Biochimica et Biophysica Acta, Biomembranes, vol. 1192, no. 1, pp. 125-131, 1994.

[161] Z. Xie, M. Jack-Hays, Y. Wang et al., "Different oxidant sensitivities of the $\alpha_{1}$ and $\alpha_{2}$ isoforms of $\mathrm{Na}^{+} / \mathrm{K}^{+}$-ATPase expressed in baculovirus-infected insect cells," Biochemical and Biophysical Research Communications, vol. 207, no. 1, pp. 155-159, 1995.

[162] M. Mense, G. Stark, and H. J. Apell, "Effects of free radicals on partial reactions of the Na,K-ATPase," Journal of Membrane Biology, vol. 156, no. 1, pp. 63-71, 1997.

[163] F. Thévenod and J. M. Friedmann, "Cadmium-mediated oxidative stress in kidney proximal tubule cells induces degradation of $\mathrm{Na}^{+} / \mathrm{K}^{+}$-ATPase through proteasomal and endo- /lysosomal proteolytic pathways," FASEB Journal, vol. 13, no. 13, pp. 1751-1761, 1999.

[164] C. N. White, G. A. Figtree, C. C. Liu et al., "Angiotensin II inhibits the $\mathrm{Na}^{+}-\mathrm{K}^{+}$pump via PKC-dependent activation of NADPH oxidase," American Journal of Physiology, Cell Physiology, vol. 296, no. 4, pp. C693-C700, 2009.

[165] G. A. Figtree, C. C. Liu, S. Bibert et al., "Reversible oxidative modification: a key mechanism of $\mathrm{Na}^{+}-\mathrm{K}^{+}$pump regulation," Circulation Research, vol. 105, no. 2, pp. 185-193, 2009.

[166] S. Bibert, C.-C. Liu, G. A. Figtree et al., "FXYD proteins reverse inhibition of the $\mathrm{Na}^{+}-\mathrm{K}^{+}$pump mediated by glutathionylation of its $\beta 1$ subunit," Journal of Biological Chemistry, vol. 286, no. 21, pp. 18562-18572, 2011.

[167] M. S. Reifenberger, K. L. Arnett, C. Gatto, and M. A. Milanick, "The reactive nitrogen species peroxynitrite is a potent inhibitor of renal Na-K-ATPase activity," American Journal of Physiology, vol. 295, no. 4, pp. F1191-F1198, 2008.

[168] C. Zhang, S. Z. Imam, S. F. Ali, and P. R. Mayeux, "Peroxynitrite and the regulation of $\mathrm{Na}^{+}, \mathrm{K}^{+}$-ATPase activity by angiotensin II in the rat proximal tubule," Nitric Oxide, vol. 7, no. 1, pp. 30-35, 2002.

[169] A. Y. Zhang, F. Yi, G. Zhang, E. Gulbins, and P. L. Li, "Lipid raft clustering and redox signaling platform formation in coronary arterial endothelial cells," Hypertension, vol. 47, no. 1, pp. 74-80, 2006.
[170] L. Zuo, M. Ushio-Fukai, S. Ikeda, L. Hilenski, N. Patrushev, and R. W. Alexander, "Caveolin-1 is essential for activation of Racl and $\mathrm{NAD}(\mathrm{P}) \mathrm{H}$ oxidase after angiotensin II type 1 receptor stimulation in vascular smooth muscle cells: role in redox signaling and vascular hypertrophy," Arteriosclerosis, Thrombosis, and Vascular Biology, vol. 25, no. 9, pp. 18241830, 2005.

[171] R. M. Touyz, "Lipid rafts take center stage in endothelial cell redox signaling by death receptors," Hypertension, vol. 47, no. 1, pp. 16-18, 2006.

[172] W. Han, H. Li, V. A. M. Villar et al., "Lipid rafts keep NADPH oxidase in the inactive state in human renal proximal tubule cells," Hypertension, vol. 51, no. 2, pp. 481-487, 2008.

[173] P. N. Seshiah, D. S. Weber, P. Rocic, L. Valppu, Y. Taniyama, and K. K. Griendling, "Angiotensin II stimulation of NAD(P)H oxidase activity: upstream mediators," Circulation Research, vol. 91, no. 5, pp. 406-413, 2002.

[174] R. M. Touyz, G. Yao, and E. L. Schiffrin, "c-Src induces phosphorylation and translocation of p47phox: role in superoxide generation by angiotensin II in human vascular smooth muscle cells," Arteriosclerosis, Thrombosis, and Vascular Biology, vol. 23, no. 6, pp. 981-987, 2003.

[175] T. M. Paravicini and R. M. Touyz, "Redox signaling in hypertension," Cardiovascular Research, vol. 71, no. 2, pp. 247-258, 2006.

[176] C. S. Wilcox and D. Gutterman, "Focus on oxidative stress in the cardiovascular and renal systems," American Journal of Physiology, Heart and Circulatory Physiology, vol. 288, no. 1, pp. H3-H6, 2005.

[177] R. M. Touyz, "Reactive oxygen species, vascular oxidative stress, and redox signaling in hypertension: what is the clinical significance?” Hypertension, vol. 44, no. 3, pp. 248252, 2004.

[178] F. Lacy, M. T. Kailasam, D. T. O'Connor, G. W. SchmidSchönbein, and R. J. Parmer, "Plasma hydrogen peroxide production in human essential hypertension: role of heredity, gender, and ethnicity," Hypertension, vol. 36, no. 5, pp. 878884, 2000.

[179] F. Lacy, D. T. O'Connor, and G. W. Schmid-Schönbein, "Plasma hydrogen peroxide production in hypertensives and normotensive subjects at genetic risk of hypertension," Journal of Hypertension, vol. 16, no. 3, pp. 291-303, 1998.

[180] N. D. Vaziri and B. Rodríguez-Iturbe, "Mechanisms of disease: oxidative stress and inflammation in the pathogenesis of hypertension," Nature Clinical Practice Nephrology, vol. 2, no. 10, pp. 582-593, 2006.

[181] C. S. Wilcox, "Oxidative stress and nitric oxide deficiency in the kidney: a critical link to hypertension?" American Journal of Physiology, Regulatory, Integrative and Comparative Physiology, vol. 289, no. 4, pp. R913-R935, 2005.

[182] W. J. Welch, "Intrarenal oxygen and hypertension," Clinical and Experimental Pharmacology and Physiology, vol. 33, no. 10, pp. 1002-1005, 2006.

[183] C. Kitiyakara, T. Chabrashvili, Y. Chen et al., "Salt intake, oxidative stress, and renal expression of NADPH oxidase and superoxide dismutase," Journal of the American Society of Nephrology, vol. 14, no. 11, pp. 2775-2782, 2003.

[184] C. Schreck and P. M. O'Connor, "NAD(P)H oxidase and renal epithelial ion transport," American Journal of Physiology, Regulatory Integrative and Comparative Physiology, vol. 300, no. 5, pp. R1023-R1029, 2011.

[185] H. J. Han, J. L. Yun, H. P. Su, H. L. Jang, and M. Taub, "High glucose-induced oxidative stress inhibits $\mathrm{Na}+$ /glucose 
cotransporter activity in renal proximal tubule cells," American Journal of Physiology, vol. 288, no. 5, pp. F988-F996, 2005.

[186] R. Juncos, N. J. Hong, and J. L. Garvin, "Differential effects of superoxide on luminal and basolateral $\mathrm{Na}^{+} / \mathrm{H}^{+}$exchange in the thick ascending limb," American Journal of Physiology, Regulatory Integrative and Comparative Physiology, vol. 290, no. 1, pp. R79-R83, 2006.

[187] A. W. Cowley, T. Mori, D. Mattson, and A. P. Zou, "Role of renal NO production in the regulation of medullary blood flow," American Journal of Physiology, Regulatory Integrative and Comparative Physiology, vol. 284, no. 6, pp. R1355R1369, 2003.

[188] A. Makino, M. M. Skelton, A. P. Zou, and A. W. Cowley, "Increased renal medullary $\mathrm{H}_{2} \mathrm{O}_{2}$ leads to hypertension," Hypertension, vol. 42, no. 1, pp. 25-30, 2003.

[189] N. E. Taylor and A. W. Cowley Jr., "Effect of renal medullary $\mathrm{H}_{2} \mathrm{O}_{2}$ on salt-induced hypertension and renal injury," American Journal of Physiology, Regulatory Integrative and Comparative Physiology, vol. 289, no. 6, pp. R1573R1579, 2005.

[190] N. E. Taylor, P. Glocka, M. Liang, and A. W. Cowley, "NADPH oxidase in the renal medulla causes oxidative stress and contributes to salt-sensitive hypertension in Dahl S rats," Hypertension, vol. 47, no. 4, pp. 692-698, 2006.

[191] C. Cao, A. Edwards, M. Sendeski et al., "Intrinsic nitric oxide and superoxide production regulates descending vasa recta contraction," American Journal of Physiology, vol. 299, no. 5, pp. F1056-F1064, 2010.

[192] A. Edwards, C. Cao, and T. L. Pallone, "Cellular mechanisms underlying nitric oxide-induced vasodilation of descending vasa recta," American Journal of Physiology, Renal Physiology, vol. 300, no. 2, pp. F441-F456, 2011.

[193] Z. Yang, L. D. Asico, P. Yu et al., "D5 dopamine receptor regulation of reactive oxygen species production, NADPH oxidase, and blood pressure," American Journal of Physiology, Regulatory Integrative and Comparative Physiology, vol. 290, no. 1, pp. R96-R104, 2006.

[194] L. Kopkan and D. S. Majid, "Superoxide contributes to development of salt sensitivity and hypertension induced by nitric oxide deficiency," Hypertension., vol. 46, no. 4, pp. 1026-1031, 2005.

[195] L. Kopkan, A. Hess, Z. Husková, L. Červenka, L. G. Navar, and D. S. A. Majid, "High-salt intake enhances superoxide activity in enos knockout mice leading to the development of salt sensitivity," American Journal of Physiology, vol. 299, no. 3, pp. F656-F663, 2010.

[196] R. Zhang, P. Hording, J. L. Garvin et al., "Isoforms and functions of $\mathrm{NAD}(\mathrm{P}) \mathrm{H}$ oxidase at the macula densa," Hypertension, vol. 53, no. 3, pp. 556-563, 2009.

[197] P. A. Ortiz and J. L. Garvin, "Superoxide stimulates $\mathrm{NaCl}$ absorption by the thick ascending limb," American Journal of Physiology, vol. 283, no. 5, pp. F957-F962, 2002.

[198] T. Mori and A. W. Cowley, "Angiotensin II-NAD(P)H oxidase-stimulated superoxide modifies tubulovascular nitric oxide cross-talk in renal outer medulla," Hypertension, vol. 42, no. 4, pp. 588-593, 2003.

[199] E. J. Johns, B. O'Shaughnessy, S. O’Neill, B. Lane, and V. Healy, "Impact of elevated dietary sodium intake on $\mathrm{NAD}(\mathrm{P}) \mathrm{H}$ oxidase and SOD in the cortex and medulla of the rat kidney," American Journal of Physiology, Regulatory Integrative and Comparative Physiology, vol. 299, no. 1, pp. R234-R240, 2010.
[200] T. Wang, "Nitric oxide regulates $\mathrm{HCO}_{3}$ and $\mathrm{Na}^{+}$transport by a cGMP-mediated mechanism in the kidney proximal tubule," American Journal of Physiology, Renal Physiology, vol. 272, no. 2, pp. F242-F248, 1997.

[201] H. Li, W. Han, A. M. Van Villar et al., "D1-like receptors regulate nadph oxidase activity and subunit expression in lipid raft microdomains of renal proximal tubule cells," Hypertension, vol. 53, no. 6, pp. 1054-1061, 2009.

[202] A. A. Banday and M. F. Lokhandwala, "Loss of biphasic effect on $\mathrm{Na} / \mathrm{K}$-ATPase activity by angiotensin II involves defective angiotensin type 1 receptor-nitric oxide signaling," Hypertension, vol. 52, no. 6, pp. 1099-1105, 2008.

[203] O. W. Moe, A. Tejedor, M. Levi, D. W. Seldin, P. A. Preisig, and R. J. Alpern, "Dietary $\mathrm{NaCl}$ modulates $\mathrm{Na}^{+}$$\mathrm{H}^{+}$antiporter activity in renal cortical apical membrane vesicles," American Journal of Physiology - Renal Fluid and Electrolyte Physiology, vol. 260, no. 1, pp. F130-F137, 1991.

[204] L. E. Yang, M. B. Sandberg, A. D. Can, K. PihakaskiMaunsbach, and A. A. McDonough, "Effects of dietary salt on renal $\mathrm{Na}^{+}$transporter subcellular distribution, abundance, and phosphorylation status," American Journal of Physiology, vol. 295, no. 4, pp. F1003-F1016, 2008.

[205] J. Liu, Y. Yan, L. Liu et al., "Impairment of Na/K-ATPase signaling in renal proximal tubule contributes to Dahl saltsensitive hypertension," Journal of Biological Chemistry, vol. 286, no. 26, pp. 22806-22813, 2011.

[206] K. A. Fisher, S. H. Lee, J. Walker, C. Dileto-Fang, L. Ginsberg, and S. R. Stapleton, "Regulation of proximal tubule sodium/hydrogen antiporter with chronic volume contraction," American Journal of Physiology, vol. 280, no. 5, pp. F922-F926, 2001.

[207] E. Silva and P. Soares-da-Silva, "Reactive oxygen species and the regulation of renal $\mathrm{Na}^{+}-\mathrm{K}^{+}$-ATPase in opossum kidney cells," American Journal of Physiology, Regulatory Integrative and Comparative Physiology, vol. 293, no. 4, pp. R1764R1770, 2007.

[208] A. A. McDonough, "Mechanisms of proximal tubule sodium transport regulation that link extracellular fluid volume and blood pressure," American Journal of Physiology, Regulatory Integrative and Comparative Physiology, vol. 298, no. 4, pp. R851-R861, 2010.

[209] L. E. Yang, P. K. K. Leong, and A. A. McDonough, "Reducing blood pressure in SHR with enalapril provokes redistribution of NHE3, NaPi2, and NCC and decreases NaPi2 and ACE abundance," American Journal of Physiology, vol. 293, no. 4, pp. F1197-F1208, 2007.

[210] T. L. Pallone, "Control of renal $\mathrm{Na}+$ excretion by heme oxygenase," Hypertension, vol. 49, no. 1, pp. 23-24, 2007.

[211] A. P. Zou, H. Billington, N. Su, and A. W. Cowley, "Expression and actions of heme oxygenase in the renal medulla of rats," Hypertension, vol. 35, no. 1, pp. 342-347, 2000.

[212] F. Rodriguez, F. Zhang, S. Dinocca, and A. Nasjletti, "Nitric oxide synthesis influences the renal vascular response to heme oxygenase inhibition," American Journal of Physiology, vol. 284, no. 6, pp. F1255-F1262, 2003.

[213] B. Arregui, B. López, M. G. Salom, F. Valero, C. Navarro, and F. J. Fenoy, "Acute renal hemodynamic effects of dimanganese decacarbonyl and cobalt protoporphyrin," Kidney International, vol. 65, no. 2, pp. 564-574, 2004.

[214] R. A. Johnson, M. Lavesa, B. Askari, N. G. Abraham, and A. Nasjletti, "A heme oxygenase product, presumably carbon monoxide, mediates a vasodepressor function in rats," Hypertension, vol. 25, no. 2, pp. 166-169, 1995. 
[215] H. Hirakawa and Y. Hayashida, "Autonomic cardiovascular responses to heme oxygenase inhibition in conscious rats," Hypertension, vol. 48, no. 6, pp. 1124-1129, 2006.

[216] R. A. Johnson, M. Lavesa, K. Deseyn, M. J. Scholer, and A. Nasjletti, "Heme oxygenase substrates acutely lower blood pressure in hypertensive rats," American Journal of Physiology, vol. 271, no. 3, pp. H1132-H1138, 1996.

[217] R. D. Levere, P. Martasek, B. Escalante, M. L. Schwartzman, and N. G. Abraham, "Effect of heme arginate administration on blood pressure in spontaneously hypertensive rats," Journal of Clinical Investigation, vol. 86, no. 1, pp. 213-219, 1990.

[218] D. Sacerdoti, B. Escalante, N. G. Abraham, J. C. McGiff, R. D. Levere, and M. L. Schwartzman, "Treatment with tin prevents the development of hypertension in spontaneously hypertensive rats," Science, vol. 243, no. 4889, pp. 388-390, 1989.

[219] H. E. Sabaawy, F. Zhang, X. Nguyen et al., "Human heme oxygenase-1 gene transfer lowers blood pressure and promotes growth in spontaneously hypertensive rats," Hypertension, vol. 38, no. 2, pp. 210-215, 2001.

[220] R. Wang, R. Shamloul, X. Wang, Q. Meng, and L. Wu, "Sustained normalization of high blood pressure in spontaneously hypertensive rats by implanted hemin pump," Hypertension, vol. 48, no. 4, pp. 685-692, 2006.

[221] F. K. Johnson, W. Durante, K. J. Peyton, and R. A. Johnson, "Heme oxygenase inhibitor restores arteriolar nitric oxide function in dahl rats," Hypertension, vol. 41, no. 1, pp. 149155, 2003.

[222] F. J. Teran, R. A. Johnson, B. K. Stevenson et al., "Heme oxygenase-derived carbon monoxide promotes arteriolar endothelial dysfunction and contributes to salt-induced hypertension in Dahl salt-sensitive rats," American Journal of Physiology, Regulatory Integrative and Comparative Physiology, vol. 288, no. 3, pp. R615-R622, 2005.

[223] R. A. Johnson, F. J. Teran, W. Durante, K. J. Peyton, and F. K. Johnson, "Enhanced heme oxygenase-mediated coronary vasodilation in Dahl salt-sensitive hypertension," American Journal of Hypertension, vol. 17, no. 1, pp. 25-30, 2004.

[224] P. Katavetin, R. Inagi, T. Miyata et al., "Erythropoietin induces heme oxygenase-1 expression and attenuates oxidative stress," Biochemical and Biophysical Research Communications, vol. 359, no. 4, pp. 928-934, 2007.

[225] T. Münzel, T. Gori, R. M. Bruno, and S. Taddei, "Is oxidative stress a therapeutic target in cardiovascular disease?" European Heart Journal, vol. 31, no. 22, pp. 2741-2748, 2010.

[226] L. J. Appel, T. J. Moore, E. Obarzanek et al., "A clinical trial of the effects of dietary patterns on blood pressure," New England Journal of Medicine, vol. 336, no. 16, pp. 1117-1124, 1997.

[227] E. R. Miller III, L. J. Appel, and T. H. Risby, "Effect of dietary patterns on measures of lipid peroxidation: results from a randomized clinical trial," Circulation, vol. 98, no. 22, pp. 2390-2395, 1998.

[228] J. H. John, S. Ziebland, P. Yudkin, L. S. Roe, and H. A. W. Neil, "Effects of fruit and vegetable consumption on plasma antioxidant concentrations and blood pressure: a randomised controlled trial," Lancet, vol. 359, no. 9322, pp. 1969-1974, 2002.

[229] R. Collins, J. Armitage, S. Parish, P. Sleight, and R. Peto, "MRC/BHF Heart Protection Study of antioxidant vitamin supplementation in 20536 high-risk individuals: a randomised placebo-controlled trial," Lancet, vol. 360, no. 9326, pp. 23-33, 2002.
[230] H. F. Galley, J. Thornton, P. D. Howdle, B. E. Walker, and N. R. Webster, "Combination oral antioxidant supplementation reduces blood pressure," Clinical Science, vol. 92, no. 4, pp. 361-365, 1997.

[231] A. Ceriello, D. Giugliano, A. Quatraro, and P. J. Lefebvre, "Anti-oxidants show an anti-hypertensive effect in diabetic and hypertensive subjects," Clinical Science, vol. 81, no. 6, pp. 739-742, 1991.

[232] A. Ceriello, E. Motz, and D. Giugliano, "Hypertension and ascorbic acid," Lancet, vol. 355, no. 9211, pp. 1272-1273, 2000.

[233] H.-Y. Huang, B. Caballero, S. Chang et al., "The efficacy and safety of multivitamin and mineral supplement use to prevent cancer and chronic disease in adults: a systematic review for a National Institutes of Health state-of-the-science conference," Annals of Internal Medicine, vol. 145, no. 5, pp. 372-385, 2006.

[234] J. L. Garvin and P. A. Ortiz, "The role of reactive oxygen species in the regulation of tubular function," Acta Physiologica Scandinavica, vol. 179, no. 3, pp. 225-232, 2003. 


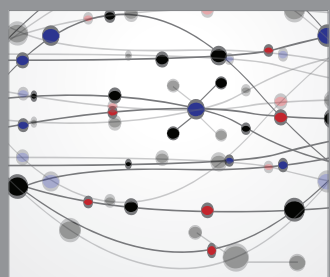

The Scientific World Journal
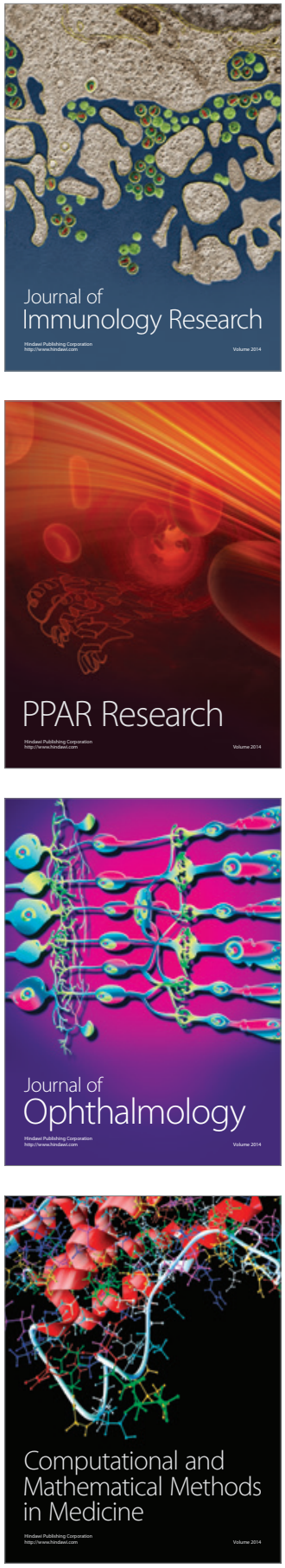

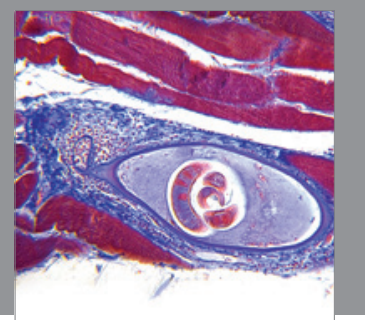

Gastroenterology

Research and Practice
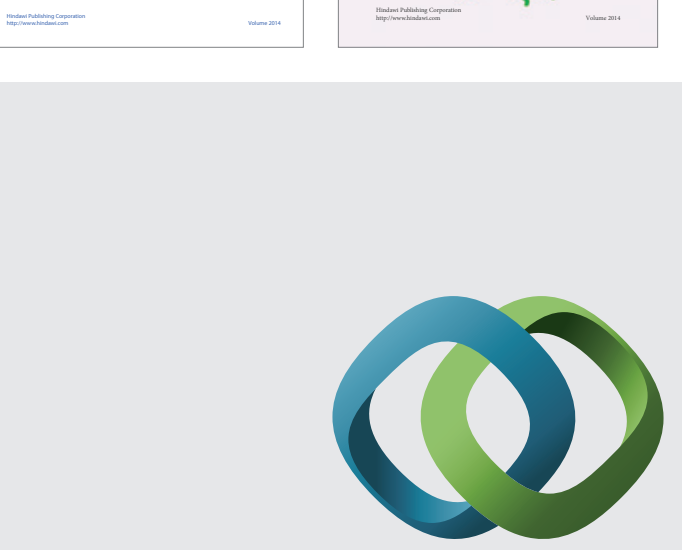

\section{Hindawi}

Submit your manuscripts at

http://www.hindawi.com
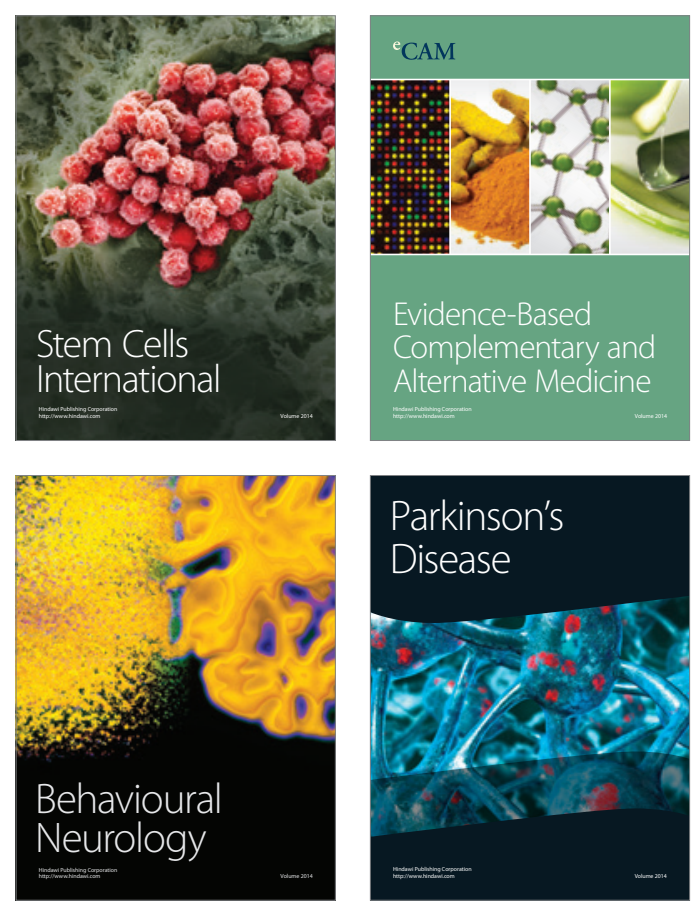

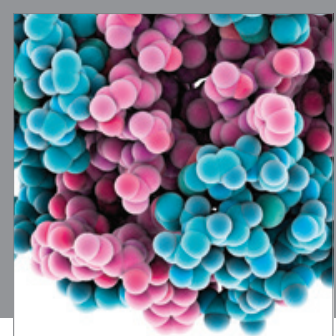

Journal of
Diabetes Research

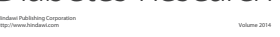

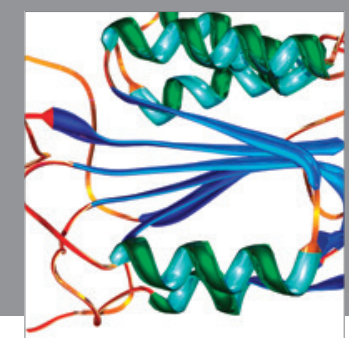

Disease Markers
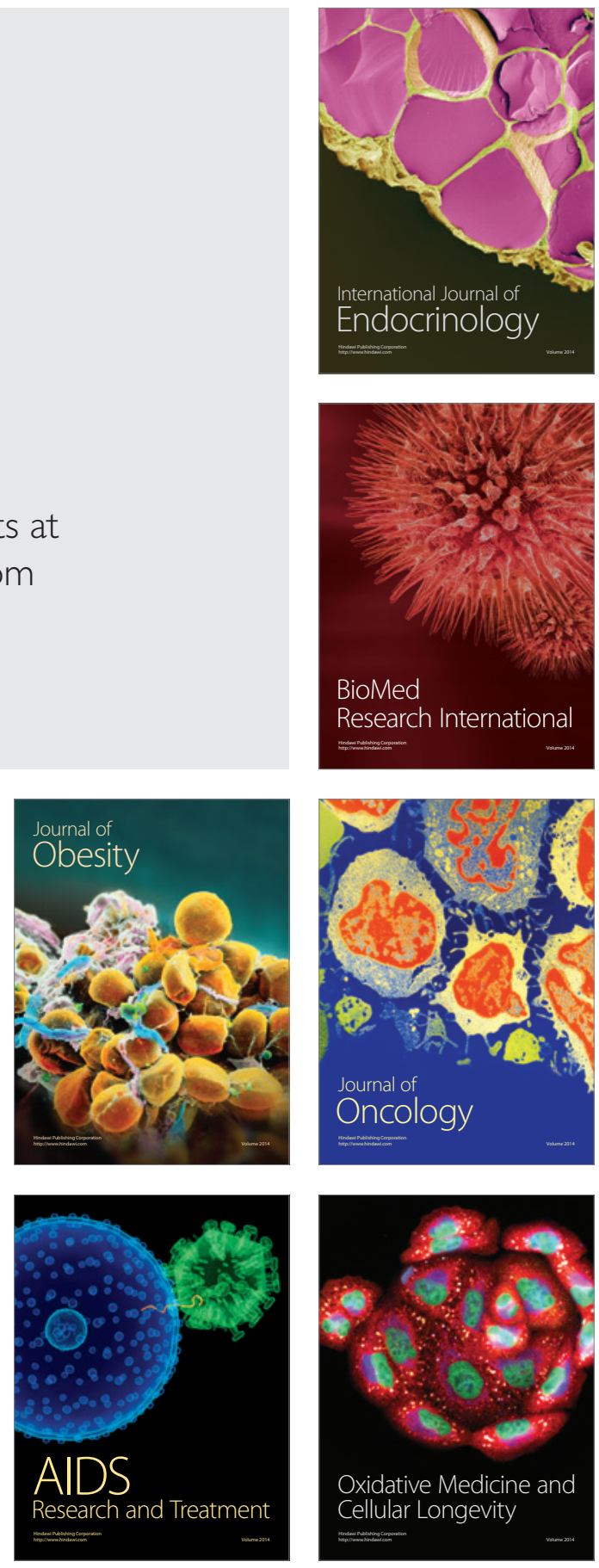